GEOLOGICAL SURVEY CIRCULAR 798

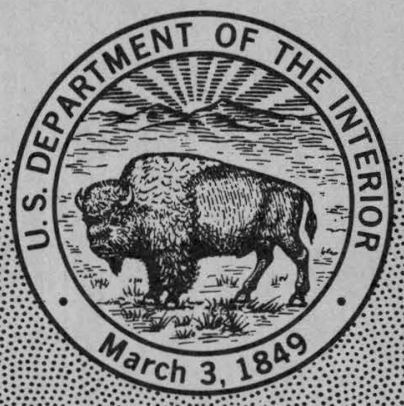

Unstable Ground in

Western North Dakota

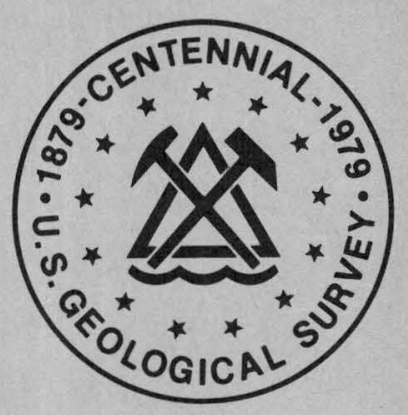





\section{Unstable Ground in}

Western North Dakota

By Donald E. Trimble

GEOLOGICAL SURVEY CIRCULAR 798

Distribution of landslides and subsidence in western North Dakota, and recognition of widespread earth slides in the unglaciated southwestern part of the state 
United States Department of the Interior CECIL D. ANDRUS, Secretary

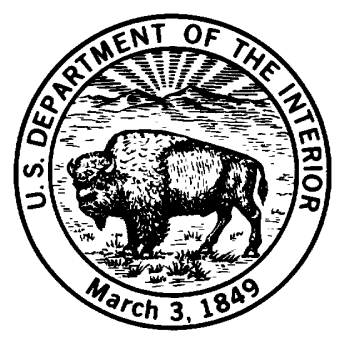

\section{Geological Survey}

H. William Menard, Director 


\section{CONTENTS}

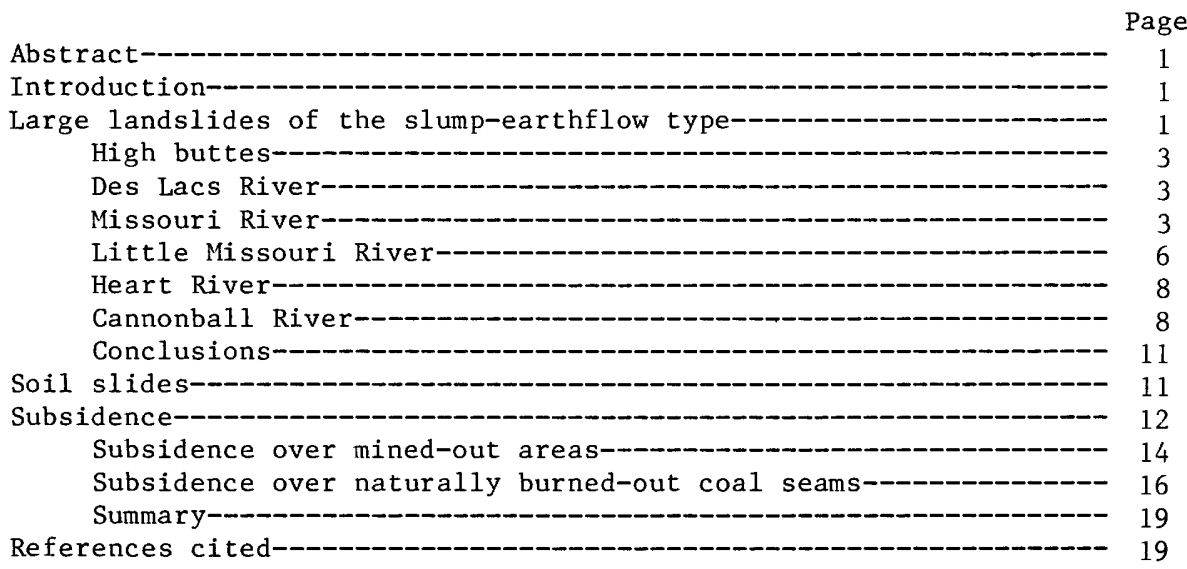

Figure 1. Location and type of unstable ground in western North Dakota----- 2

2. Landslide on northeast side of HT (Black) Butte---------

3. Landslides on west side of North Chalky Butte-

4. Landslides on northwest side of West Rainy Butte--------

5. Landslides on southwest side of Sentinel Butte----------

6. Landslides on east side of Killdeer Mountains----------

7. Large old landslide complex in Shipton Coulee------------

8. Recent landslide on north-facing slope south of

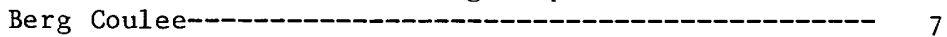

9. Tongue River Member of the Fort Union Formation---------

10. Large landslide complex on east side of the Missouri River-

11. Landslide area on north side of Bear Den Creek--_----

12. Landslides on south side of Little Missouri River-------

13. Recent landslide south of Little Missouri River---------

14. Tilted slump blocks in Fort Union Formation------------

15. Badlands east of Little Missouri River---_------------

16. Landslide along south side of the Heart River valley----

17. Sentinel Butte Member of the Fort Union Formation-------

18. Landslides along east side of Heart River valley--.-----

19. Soil slide scars on west-facing slope, south of

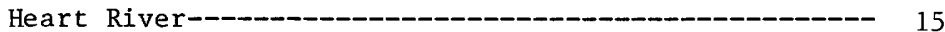

20. Soil slide scars on north end of Chalky Buttes---_-_-_ 15

21. Subsidence pits over old underground coal mine workings near Beulah, North Dakota--_----_------- 16

22. Aerial view northwest across subsidence pits----------- 17

23. Aerial view looking northwest across a subsidence area and an Arrowhead Coal Company strip mine---------- 17

24. View looking west to the Burning Coal Vein subsidence

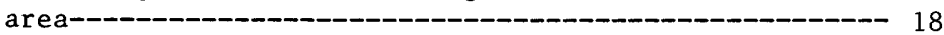

25. Subsidence above a burning underground 1ignite bed------- 18 



\title{
UNSTABLE GROUND IN WESTERN NORTH DAKOTA
}

\author{
By Donald E. Trimble
}

\begin{abstract}
Unstable ground in western North Dakota is mainly the result of mass-wasting processes. The units most affected are mudstones, siltstones, and sandstones of the Fort Union Formation. Ground instability generally is indicated by landslides, soil slides, or subsidence.

Landslides are mostly of the slumpearthflow type and are localized along the flanks of the high buttes in southwestern North Dakota, including HT (Black) Butte, Chalky Buttes, Sentine1 Butte, and East and West Rainy Buttes, and along parts of the valleys of the Des Lacs, Missouri, Little Missouri, and Heart Rivers. Landslides are sparse elsewhere.

Soil slides are common in the areas south and southwest of the maximum position of the Pleistocene glacial ice margin on slopes of 15 degrees or more, and have taken place on some slopes as gentle as five degrees. The weathered, exposed surface of the Fort Union Formation seems to be especially susceptible to soil slides. Soil slides constitute the major type of ground instability in southwestern North Dakota.
\end{abstract}

Subsidence is of two types: (1) subsidence over old underground mine workings, and

(2) subsidence over naturally ignited and burned underground coal beds. Major subsidence has taken place over old, underground workings near Beulah, Wilton, Lehigh, Haynes, and Belfield, and lesser subsidence near Scranton, and west and north of Bowman. Thickness of overburden above the coal in all these areas is believed to be less than $30 \mathrm{~m}(100 \mathrm{ft})$. Subsidence has not taken place over old underground workings along the Des Lacs and Souris valleys northwest of Minot, where the thickness of overburden is more than $60 \mathrm{~m}$ ( $200 \mathrm{ft})$.

Spectacular subsidence has occurred over a burning underground coal bed at Burning Coal Vein Park near the Little Missouri River, northwest of Amidon.

\section{INTRODUCTION}

Huge landslides, abundant soil slide scars, and deep subsidence pits are convincing evidence of past ground instability in western North Dakota. These failures were mainly the result of mass-wasting processes affecting the mudstones and siltstones that form most of the Fort Union Formation, the bedrock for virtually the entire area. North of the Missouri River the bedrock is largely covered by glacial drift. Large slump-earthflow landslides are localized mainly along the valley walls of a few deeply entrenched streams. Small but abundant soil slides are widespread in the unglaciated areas of the southwest part of the State. Spectacular ground subsidence, both over old underground mines and over naturally ignited and burned coal beds, has occurred in many places in western North Dakota.

This record of past failures is an indication that similar failures may occur in the future, and this potential for ground instability is a subject for consideration in planning for energy development as well as for highway, railroad, and transmission line construction.

The information presented here is intended to inform developmental planners of the location and extent of past ground failures (fig. 1), and to provide information for evaluating the potential hazard related to future ground instability at localities in western North Dakota.

\section{LARGE LANDSLIDES OF THE SLUMP-EARTHFLOW TYPE}

Slumps are landslides characterized by shearing and rotational movement of an independent mass of rock or earth along a curved slip surface. Beds within the discrete mass become tilted backward and downward toward the slope (definition of slump modified from American Geological Institute, 1972). The distal parts of slump masses commonly become saturated and flow into lobate margins. This 


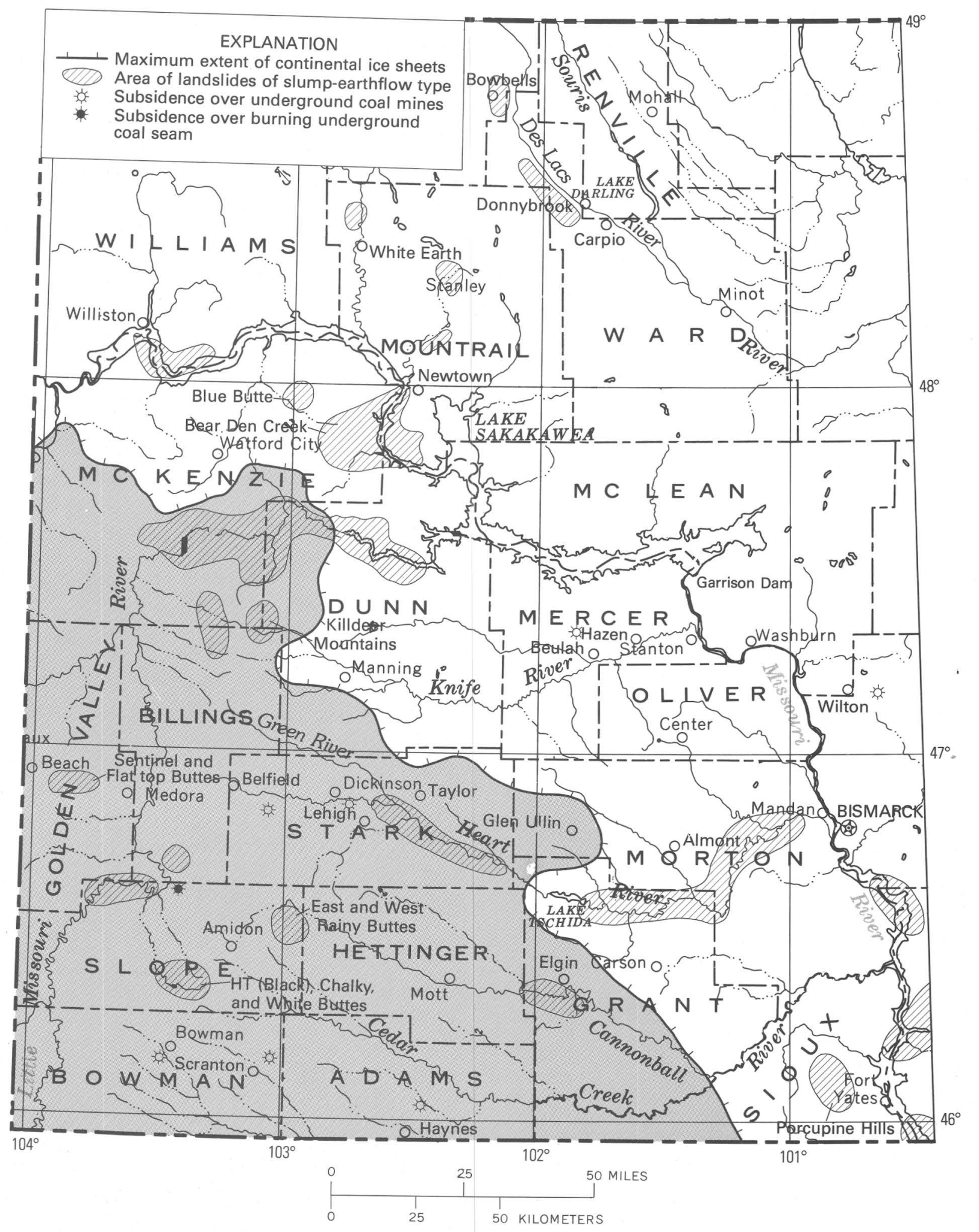

Figure 1.--Location and type of unstable ground in western North Dakota. 
combined form is termed a slump-earthflow type of landslide.

Spectacularly large landslides of the slump-earthflow type occur mainly in five areas in western North Dakota. Four of these are along or near four major rivers--from north to south, the Des Lacs, Missouri, Little Missouri, and Heart Rivers. The fifth area comprises the landslides flanking the high buttes of southwestern North Dakota.

\section{HIGH BUTTES}

A number of high buttes stand 122-153 m (400-500 ft) above the upland level, mostly in Slope and Golden Valley Counties. These include HT (Black) Butte (fig. 2), Chalky Buttes (fig. 3), White Butte, and East and West Rainy Buttes (fig. 4) in Slope County, and Sentinel Butte (fig. 5) and Flat Top Butte in Golden Valley County. These buttes are all erosional remnants of the Paleocene Fort Union Formation capped by the Oligocene White River Group. The basal part of the White River Group, the Chadron Formation, commmonly forms a resistant caprock that causes oversteepening of the slopes below. Average annual precipitation in most of this part of the state is between 38 and $41 \mathrm{~cm}$ (15 and 16 inches) a year.

All of these buttes are almost completely flanked by landslide deposits that in many places head in huge amphitheaters having nearly vertical headwall scarps. In addition, abundant landslides flank the Killdeer Mountains (fig. 6), south of the Little Missouri River; Blue Buttes, north of the Little Missouri River; and the Porcupine Hills, on the Standing Rock Indian Reservation west of the Missouri River. The landslide deposits are the result of many coalescing and overlapping slump-earthflow landslides of a wide range in age. Although some are younger, most of them were probably formed during the Pleistocene, when precipitation was greater than it is now.

\section{DES LACS RIVER}

Few landslides have taken place in the drift-covered areas north of the Missouri River. With the exception of a large landslide along the valley of the White Earth River, about $8 \mathrm{~km}$ ( $5 \mathrm{mi}$ ) north of White Earth, and some along the Little Knife River, the only important area of large landslides in the region north of the Missouri River is along the west side of the Des Lacs River and in some of its tributary coulees. At the mouth of Stony Creek, east of Bowbells, and for about $3 \mathrm{~km}$ ( 2 -miles) to the south, there are large slump landslides along Upper Des Lacs Lake. The southernmost is at the north end of a valley-wall exposure of the Fort Union Formation. The drift cover at the other localities near here is presumably thin, inasmuch as Lemke and Kaye (1953), who mapped these landslides in the Bowbells quadrangle, report "only till exposed in slide areas but failure of underlying beds of the Fort Union Formation is probably responsible for sliding".

About $16 \mathrm{~km}$ ( $10 \mathrm{mi})$ farther south, along the west side of the lower end of Lower Des Lacs Lake and in every coulee tributary entering the Des Lacs Valley from the west between Lower Des Lacs Lake and Donnybrook, there are large landslides and landslide complexes of the slumpearthflow type, some nearly a mile long (fig. 7). Many of these slides are quite old, perhaps Pleistocene, but others, especially a number of slides along the west wall of the Des Lacs Valley between Berg Coulee and Aennis Coulee (about a mile north of Donnybrook), are very recent ( $f i g$. 8 ).

The Fort Union Formation is exposed at many places along the western wall of the Des Lacs valley north of Donnybrook (fig. 9), and this exposure of bedrock at the surface obviously is in part responsible for the prevalence of landslides in this area. Steep slopes $45-60 \mathrm{~m}$ (150-200 ft) high along the valley walls contribute to instability, and Lemke and Kaye, (1953) pointed out that in the Bowbells quadrangle the flow of ground water, in lignite beds of the Fort Union Formation and at the contact between the Fort Union and the overlying drift, was to the northeast. They suggest that this would cause saturation of the beds on the west wall of the Des Lacs valley, where the ground water emerged, and would probably contribute to the sliding. The situation undoubtedly is the same in the segment between Lower Des Lacs Lake and Donnybrook, which accounts for the abundance of landslides west of the river and the lack of them east of the river. Thus, it seems likely that a combination of many factors contributed to the formation of landslides along the Des Lacs valley, including the exposure of bedrock at the surface or at a shallow depth along valley walls, the steepness and height of valley wall or bluff, the hydrologic nature of the ground-water system, and the nature and amount of precipitation.

\section{MISSOURI RIVER}

Landslides occur along the Missouri River-mainly along two reaches, one extending about 32 $\mathrm{km}$ (20 miles) downstream from Williston and the other extending about the same distance downstream from the bridge crossing of state Highway 23 near Newtown (fig. 10). The east valley wall of the Missouri, south of the bridge near Newtown, is a landslide area about two miles long. A similar slide area is located along the west side of the reservoir north of the mouth of Bear Den Creek. A few other slides exist along the reservoir walls, but many lie near the heads of small reentrants or short 


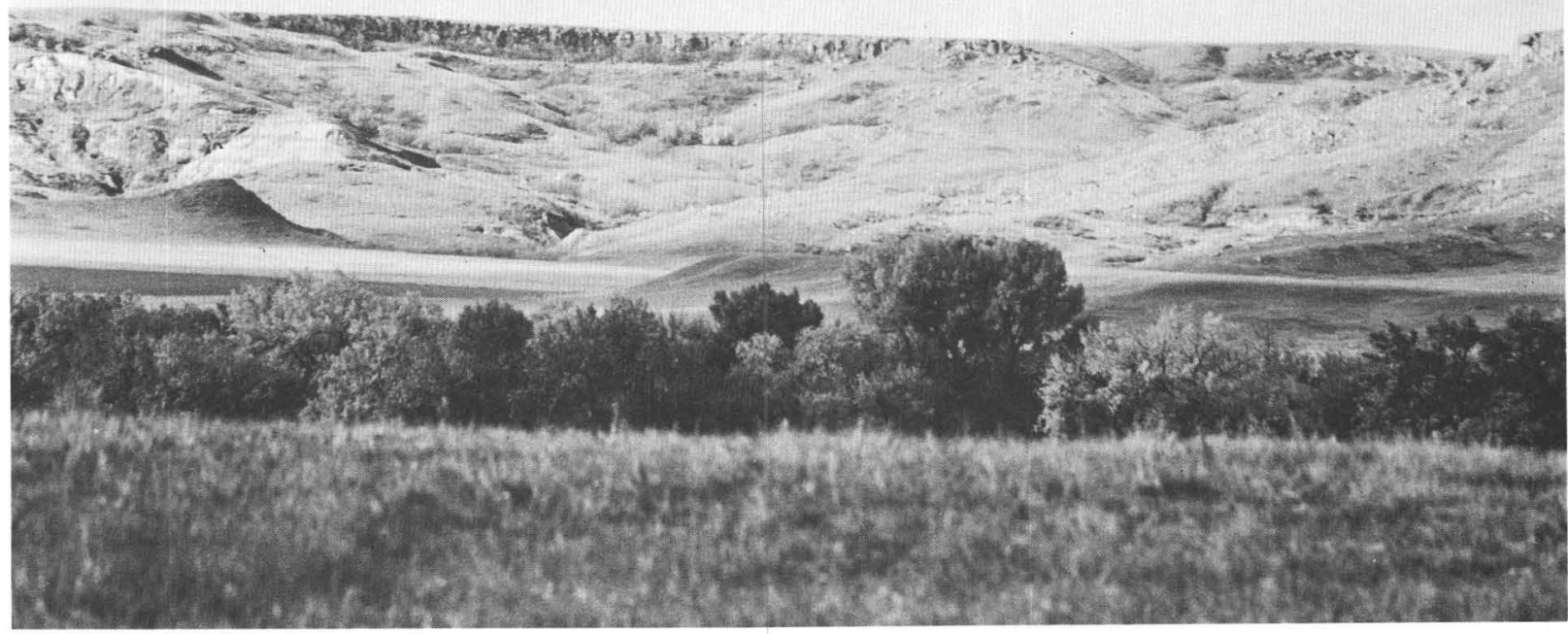

Figure 2.--Landslide complex on northeast side of HT (Black) Butte. Caprock is Oligocene Chadron Formation. Most of slide mass is in Sentinel Butte Member of the Paleocene Fort Union Formation.

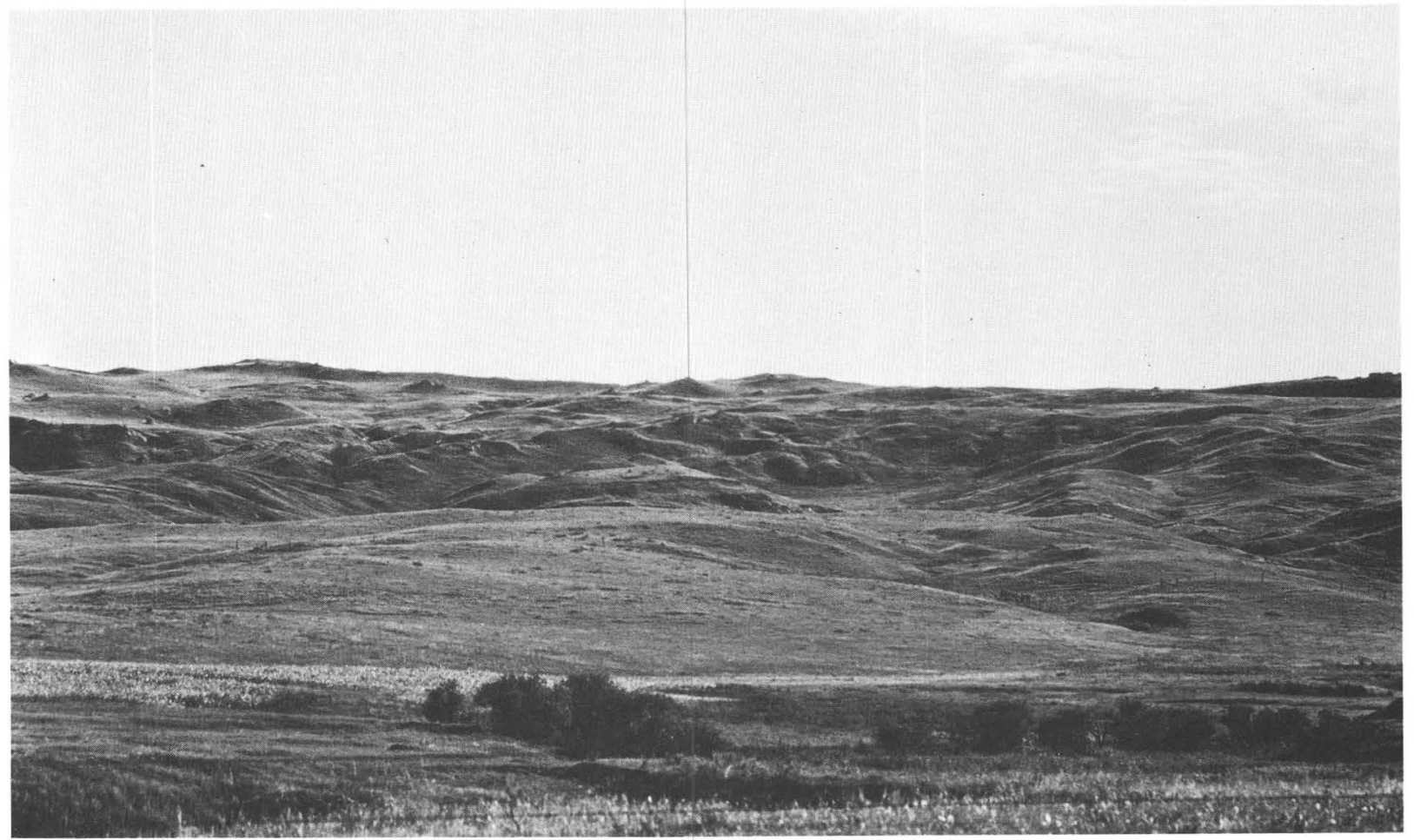

Figure 3.--Landslides on west side of North Chalky Butte, in Sentinel Butte Member of Paleocene Fort Union Formation capped by Oligocene Chadron Formation. Landslide mass covering most of slope is composed of a complex of slump-earthflow type landslides. 


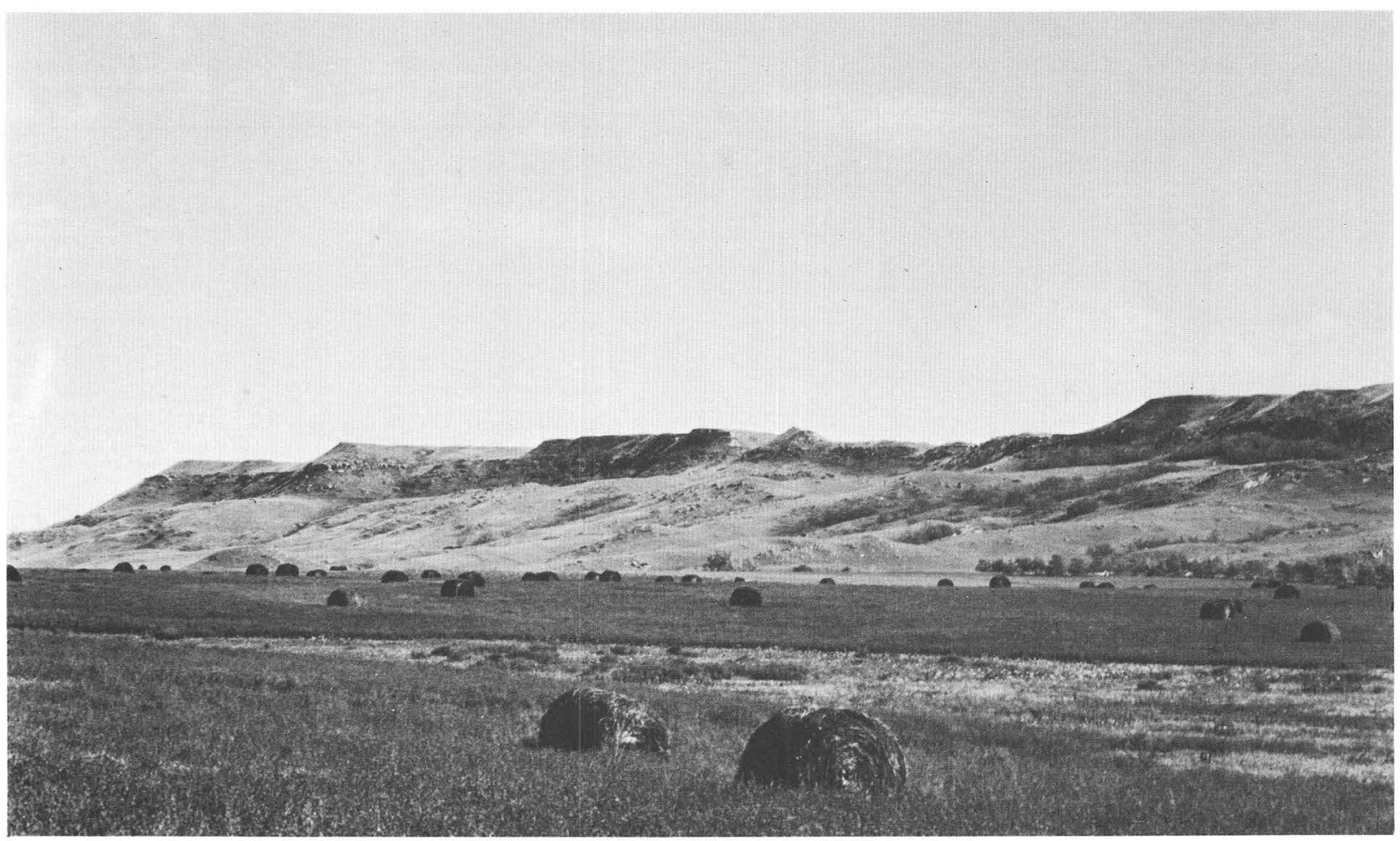

Figure 4.--Landslides on northwest side of West Rainy Butte. Entire slope below steep upper face is landslide complex.

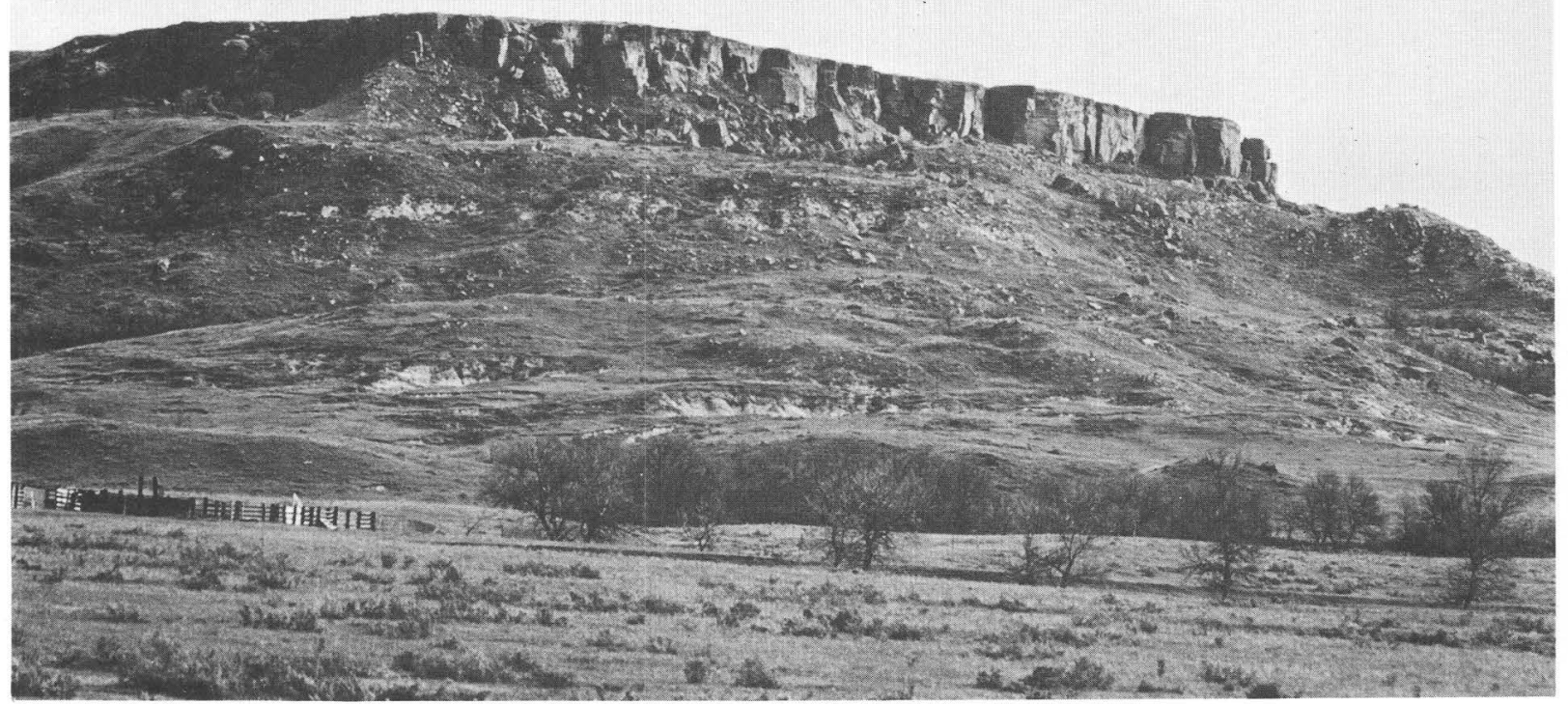

Figure 5.--Landslides on southwest side of Sentinel Butte. Caprock is Oligocene Chadron Formation overlying Sentinel Butte Member of the Fort Union Formation. Nearly entire slope below Chadron cliffs is landslide complex. 


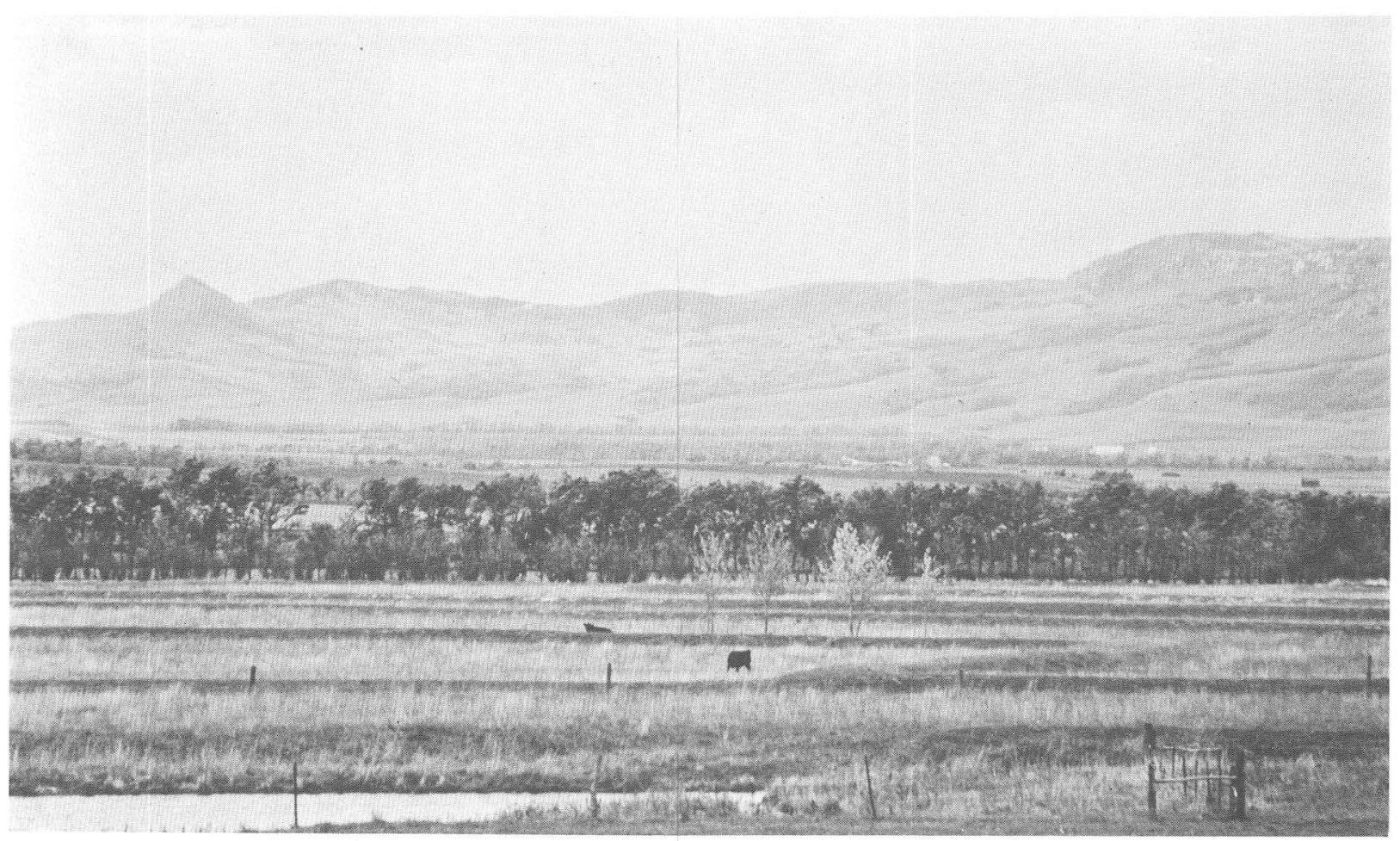

Figure 6.--Landslides on east side of Killdeer Mountains. Nearly all of the slope shown in this view is a landslide complex composed of slump-earthflow type landslides.

tributaries to the reservoir in Mountrail and McKenzie Counties, including several slides in the valley of Bear Den Creek, where it is crossed by State Highway 22 (fig. 11).

Landslides along the river near Williston are few and smaller. One is on the south side of the river, directly south of Williston, and one is on the east side of the river, southeast of Williston. Only a few other large slides occur along the river downstream. The bluffs of the Missouri River, along both reaches containing large slump-earthflow type landslides, are about $91.5 \mathrm{~m}$ (300 ft) high, mostly in Fort Union Formation (Tongue River and Sentinel Butte Members).

Other large landslides occur sporadically along the Missouri River between Bismarck and the South Dakota border. An especially large landslide complex exists on the west bank of the river near the South Dakota border.

\section{LITTLE MISSOURI RIVER}

The largest and most numerous landslides in the State of North Dakota are along the easttrending valley of the Little Missouri River between Redwing Creek (west of Theodore Roosevelt National Memorial Park, North Unit) and Lake Sakakawea (about $16 \mathrm{~km}$, or $10 \mathrm{mi}$, downriver from Lost Bridge on State Highway 22) where landslides are nearly continuous along the valley walls (fig. 12). They occur on both the north and south sides as single slumps and as landslide complexes. Some are very old, perhaps dating back to the time when this part of the valley was cut as a diversion channel along the front of the last Pleistocene ice sheet, but others are very young--having formed only recently (fig. 13). Some rotated slump blocks in Theodore Roosevelt National Memorial Park, North Unit, are very large, and the rotation is so spectacularly illustrated by tilted blocks of the layered Fort Union Formation that they are the subject of one of the main point-of-interest stops in the park (fig. 14).

This east-trending part of the Little Missouri River valley is very narrow compared with the north-trending course, ranging from as little as $1.6 \mathrm{~km}$ ( $1 \mathrm{mi}$ ) to as much as $14.5 \mathrm{~km}$ ( $9 \mathrm{mi}$ ) in width. The valley walls, where unmodified by landslides, are nearly vertical and $122-153.5 \mathrm{~m} \mathrm{(400-500} \mathrm{ft)} \mathrm{high.}$

Landslides are also abundant in tributary valleys south of the Little Missouri River in the southeastern part of McKenzie County, especially toward the heads of Bennet Creek, Corral Creek, and Crosby Creek.

The only other area of extensive landslide activity along the Little Missouri River is 


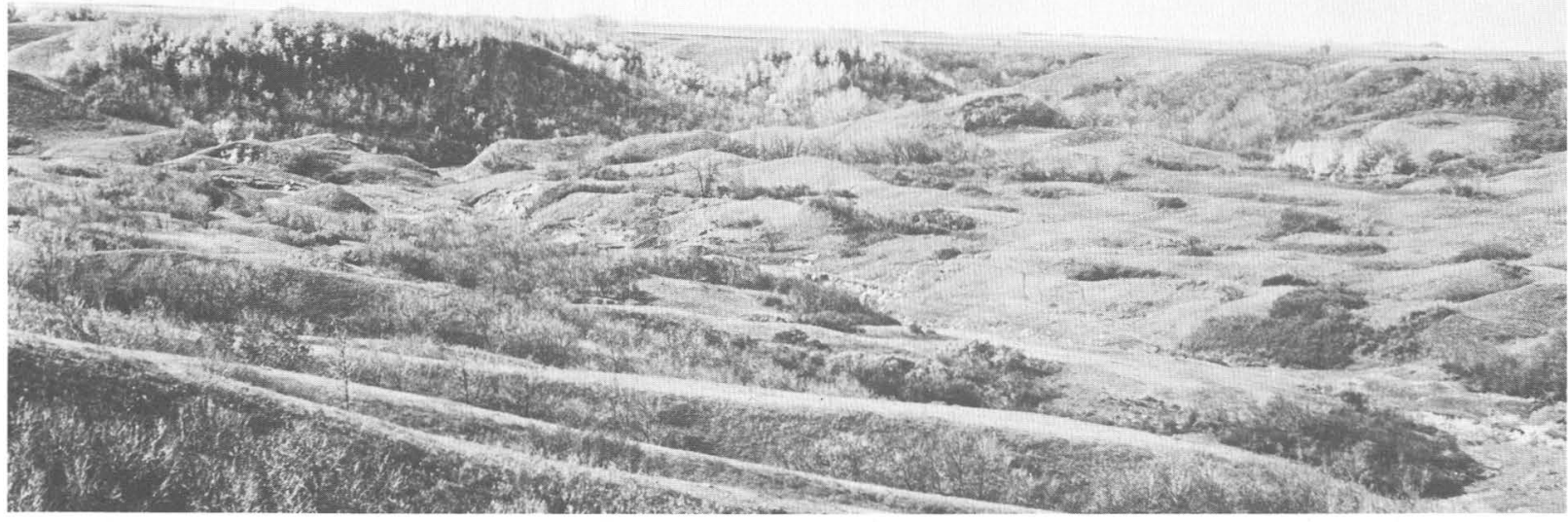

Figure 7.--Large old landslide complex in Shipton Coulee, west of the Des Lacs River near Donnybrook, North Dakota. Nearly all of the material below the level of the flat upland is landslide complex.

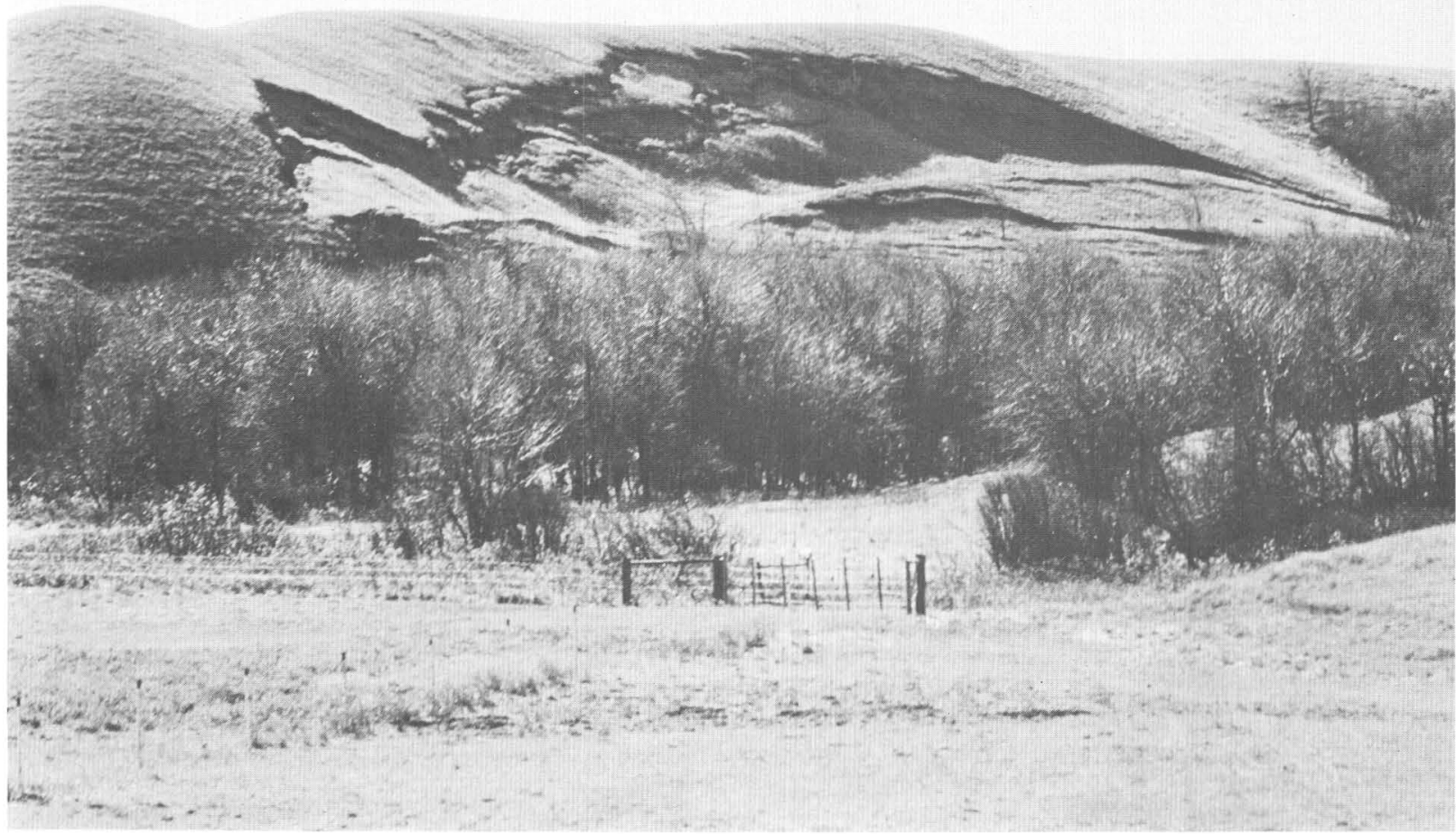

Figure 8.--Recent landslide on north-facing slope south of Berg Coulee and north of Donnybrook, North Dakota, on the west side of the Des Lacs River valley. 


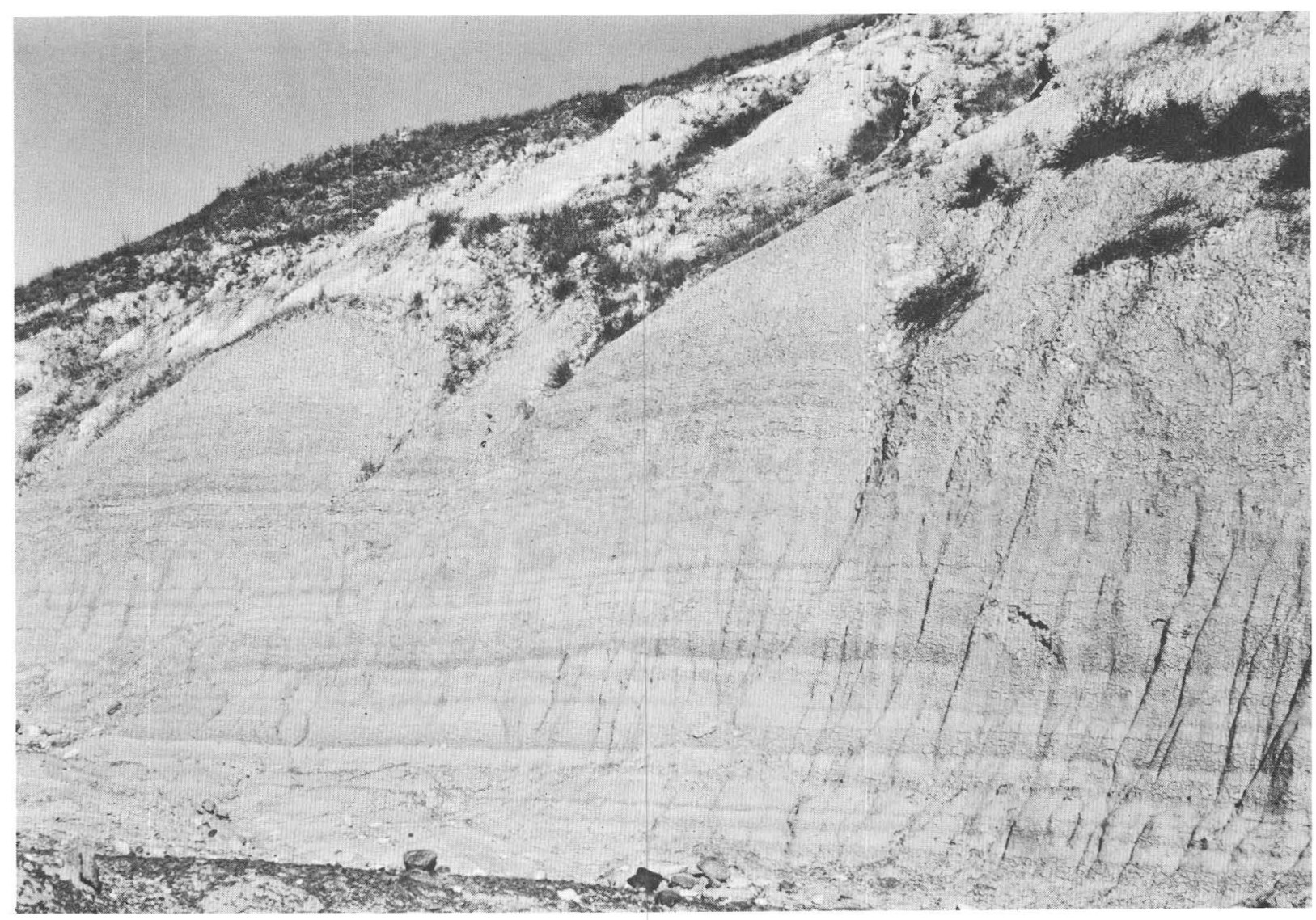

Figure 9.--Tongue River Member of the Fort Union Formation at the mouth of Baden Coulee, west side of the Des Lacs River valley at the south end of Lower Des Lac Lake. Exposure about $15 \mathrm{~m}$ (50 ft) high.

along another east-trending reach in the northern part of Slope County. There too, the valley of the Little Missouri River is narrowed from its normal width along its north-trending course, where it commonly is 20-32 km (15-20 mi) wide and deeply dissected into badlands (fig. 15) that are largely free of slumps. Local relief apparently was insufficient to induce slumping. The slides in this easttrending part of the Little Missouri River valley are smaller than those farther north, and nearly all of them are on steep cutbanks, 61-91.5 m (200-300 ft) high, at the bends of large meander loops of the Little Missouri River.

\section{HEART RIVER}

Landslides occur along the Heart River from its junction with the Green River, about $16 \mathrm{~km}$ ( $10 \mathrm{mi}$ ) east of Dickinson, to the upper end of Lake Tschida, and from the lower end of Lake Tschida almost to Mandan. Above Lake Tschida, the slides are in the Tongue River Member of the Fort Union Formation, and they occur mostly on the northeast-facing bluffs on the bends of meander loops (fig. 16). Only a few are on the southwest-facing bluffs on the north side of the river. The bluffs commonly are about $30.5 \mathrm{~m}$ (100 ft) high (fig. 17).

Between Lake Tschida and Mandan the slides are in the Cannonball Member of the Fort Union Formation. They are particularly abundant along the north-trending course in Morton County, especially on the west side of the river (fig. 18). The bluffs along this part of the river generally are 30.5-61 m (100-200 ft) high.

Landslides also occur in the Cannonball Member along the Sweet Briar tributary of the Heart River between U.S. Highway 10 and the junction with the Heart River.

\section{CANNONBALL RIVER}

The only other area of large landslides in western North Dakota is along the Cannonball River from southeast of Elgin to just below the junction with Snake Creek. These few slides are mostly in the Cannonball Member of the Fort Union Formation and are smaller than those of other areas, perhaps because of lower height and gentler slopes of valley walls. 


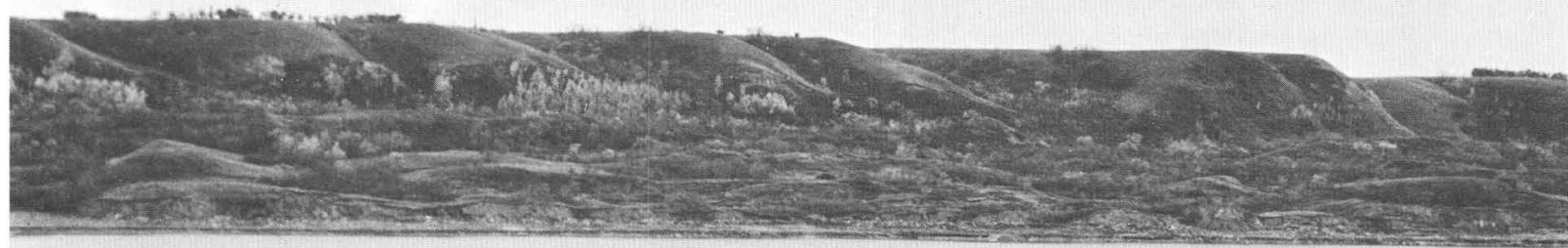

Figure 10.--Large landslide complex on east side of the Missouri River south of bridge on State Highway 23, west of Newtown, North Dakota. Several scarps at head of slumps are apparent above landslide debris in left half of picture.

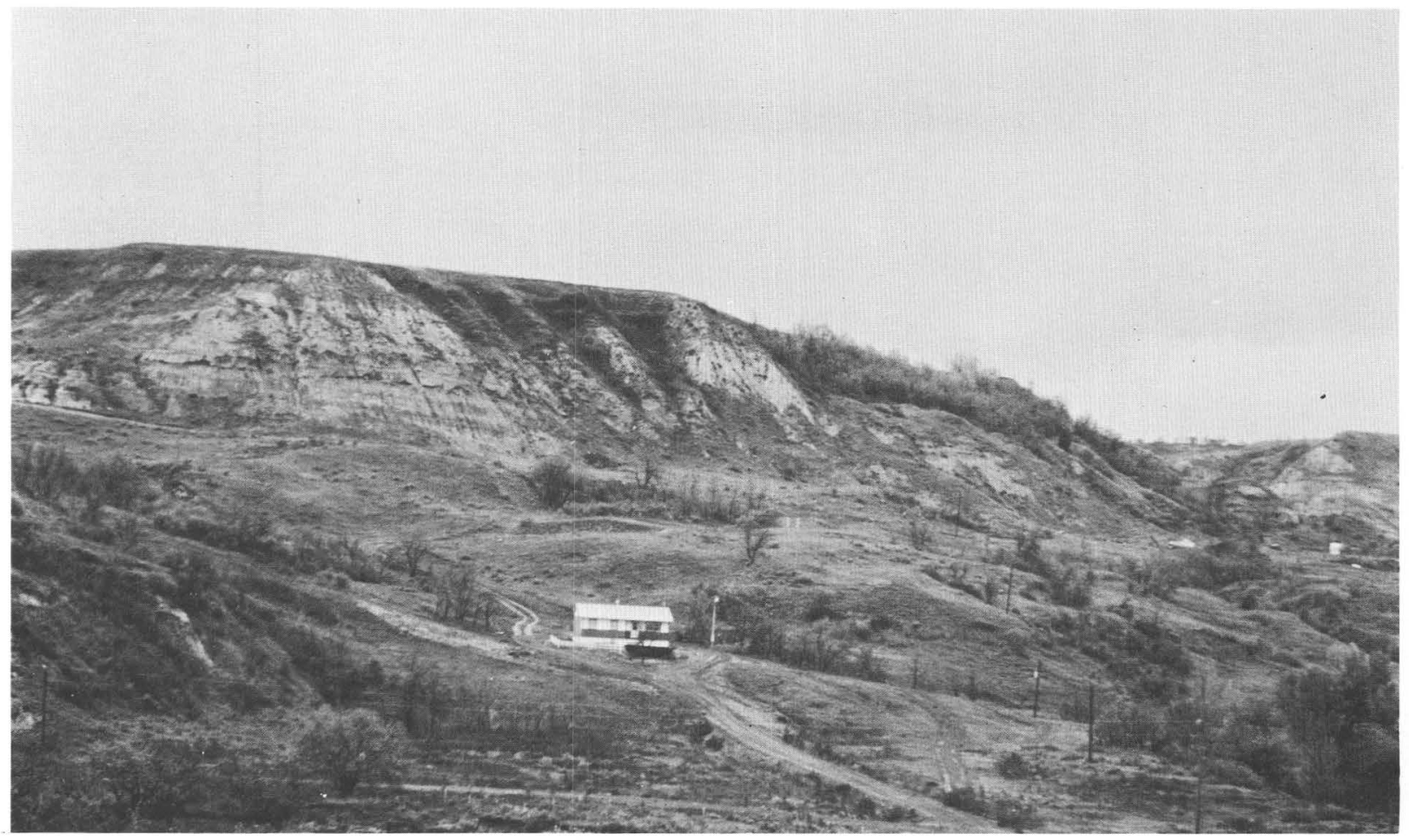

Figure 11.--Landslide area on north side of Bear Den Creek, west of State Highway 22. House is on stabilized landslide material, which also forms slope to base of light-colored bedrock exposure. 


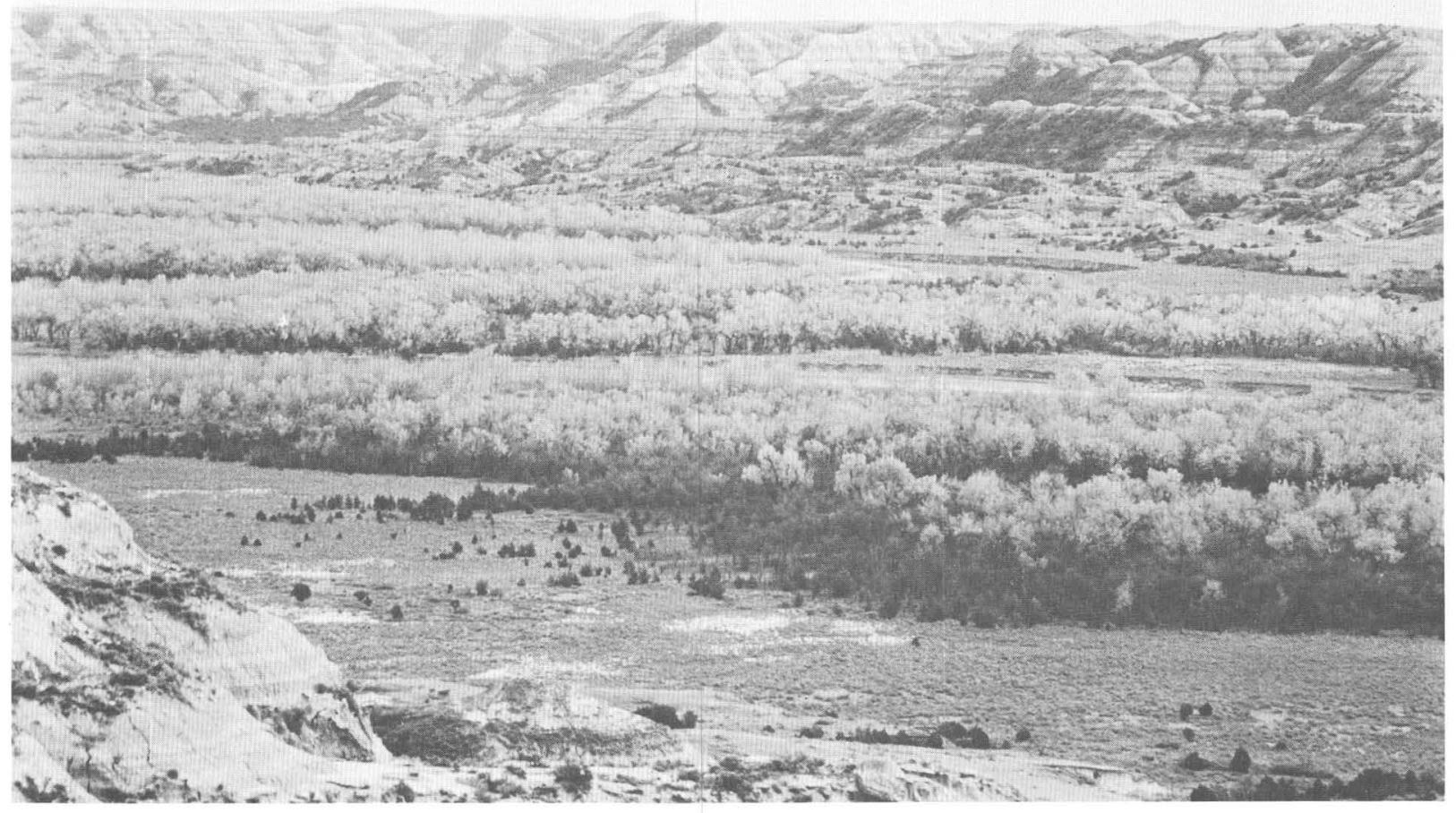

Figure 12.--Landslides on south side of Little Missouri River in Theodore Roosevelt National Memorial Park, North Unit. View from River Bend Overlook. Killdeer Mountains on skyline in left distance. Lower third of valley wall on opposite (south) side of river is landslide complex.

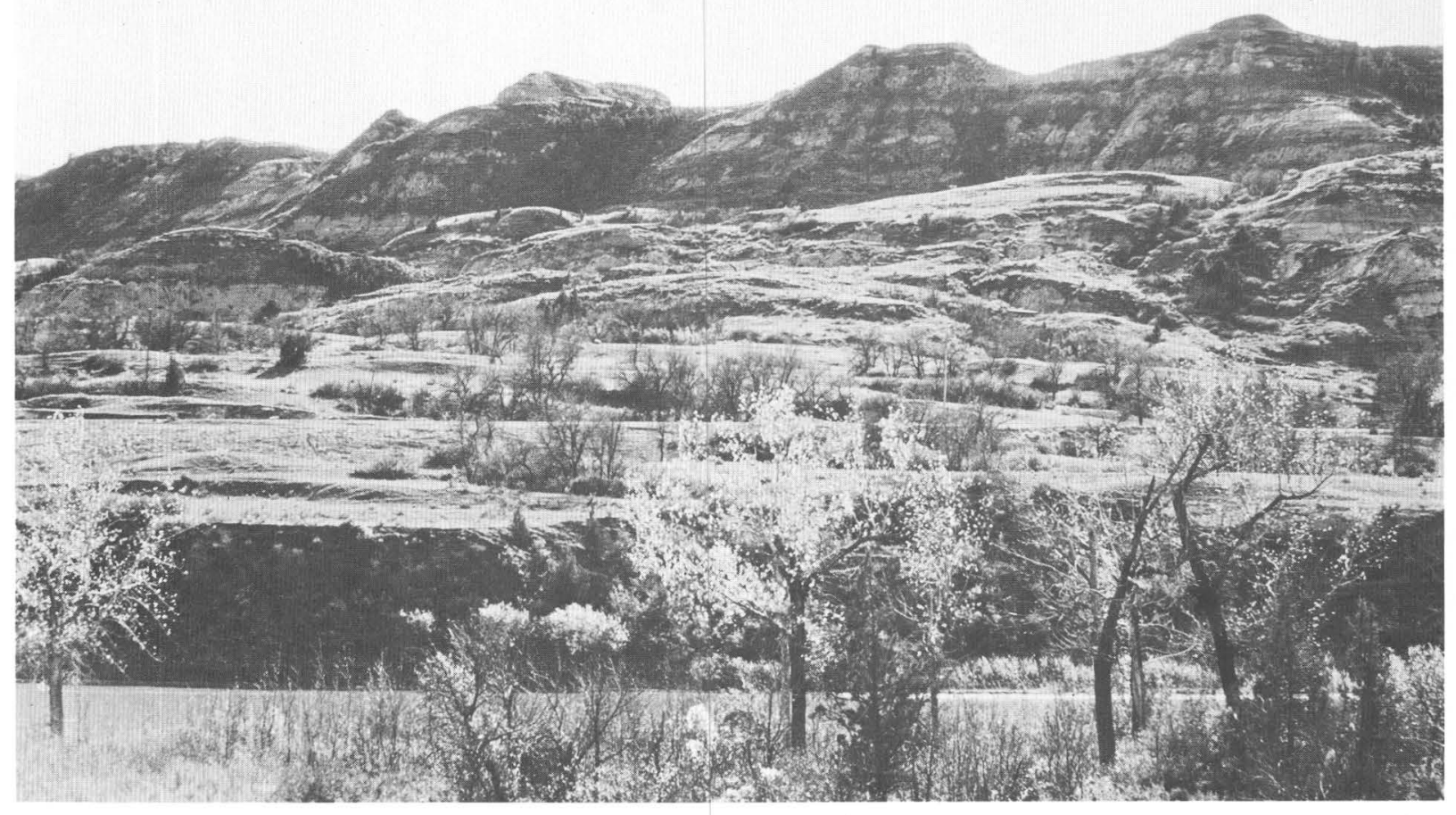

Figure 13.--Recent landslide south of the Little Missouri River, west of U.S. Highway 85. 


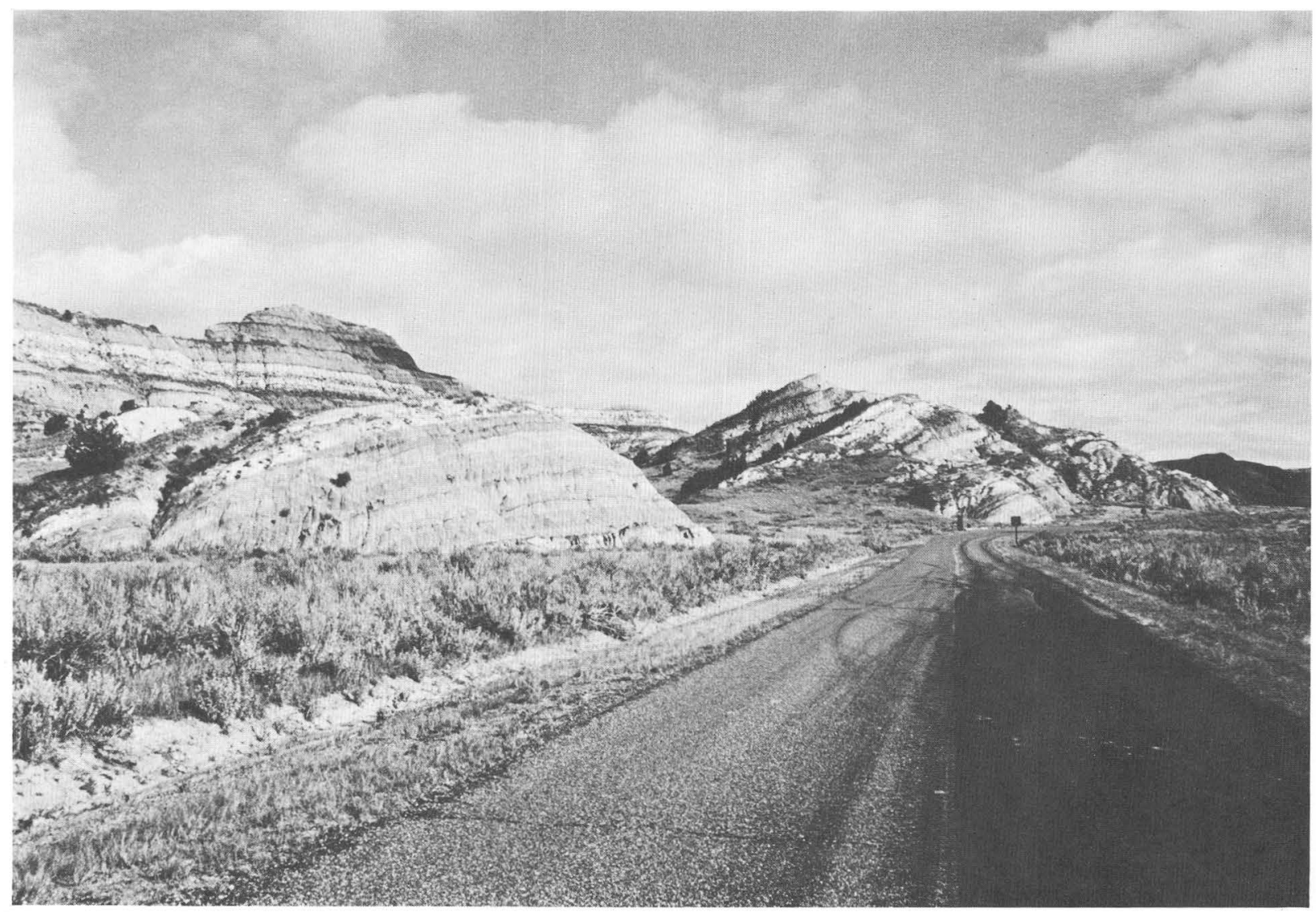

Figure 14.--Tilted slump blocks in Fort Union Formation in Theodore Roosevelt National Memorial Park, North Unit. Note horizontal bedding in undisturbed formation on skyline.

\section{CONCLUSIONS}

In summary, it appears that large landslides of the slump-earthflow type occur only where a special set of circumstances is present. A steep valley wall at least $30 \mathrm{~m}$ (100 ft) high seems to be necessary in most areas, although locally, as along the Cannonball River, some sliding takes place where valley walls are not as steep or high. Exposed bedrock of all members of the Fort Union Formation is susceptible to landsliding when other conditions are met. Wetting of the mudstone and siltstone bedrock by ground water flow or surface water helps cause sliding by adding weight to the mass and by reducing internal friction. Thus, topography, lithology, and water all seem to be primary factors in causing large landslides of the slump-earthflow type in western North Dakota.

\section{SOIL SLIDES}

A soil slide is a downslope movement of a coherent thin plate of soil and weathered rock. The thickness of the plate seems to be determined by the depth to the $\mathrm{B}$ horizon in the soil profile, where there is a high concentration of clay. The sliding takes place at the top of the clayey B horizon. The soil above the $B$ horizon consists of the $A$ and $A$ horizons, which together essentially form the root zone of the grassy vegetation growing in this area. This part of the soil profile is open and porous, and rapidly becomes saturated during heavy precipitation. The less permeable B horizon, however, tends to divert downwardmoving soil water downslope. Saturation greatly increases the weight of the soil plate above the $\mathrm{B}$ horizon, and in many places this increased weight is sufficient to overcome the tensile strength of the material and the plate tears loose and slides downhill. This movement generally is only a few feet or less.

A soil slide, then, is a type of landslide that moves primarily by gliding of a detached plate rather than by block rotation. Gravity is the primary cause of movement, but saturation of the mass is necessary for movement to occur. Because soil slides affect only near-surface soil and weathered rock, the depths affected by such slides are shallow. Large areas, however, such as entire hillsides, can be affected by multiple soil slides. 


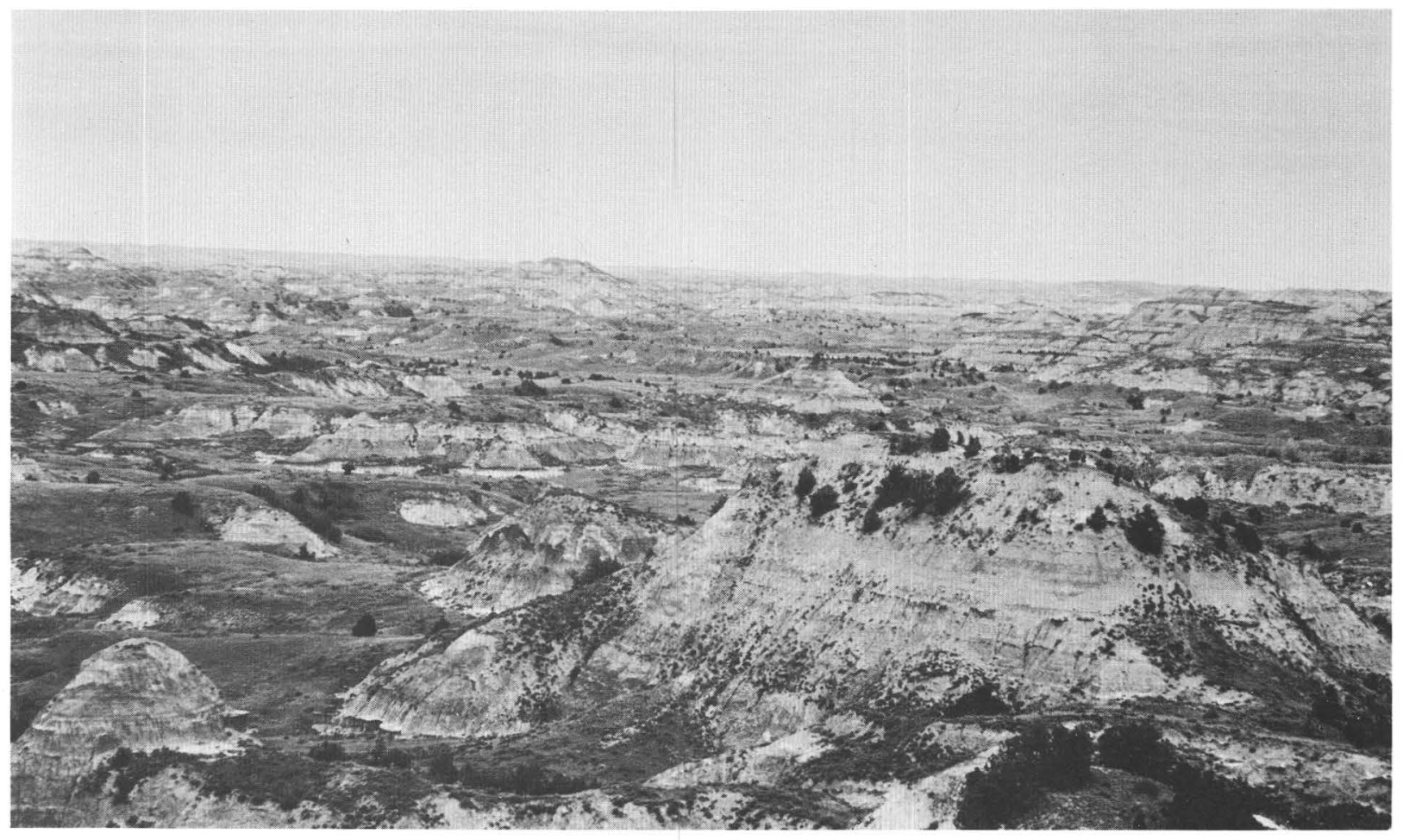

Figure 15.--Badlands east of the Little Missouri River. Local relief is apparently too low to produce large slumps. View from Painted Canyon Overlook, north side of Interstate Highway 94 west of Belfield, North Dakota.

Soil slides have affected large areas in southwestern North Dakota where the Fort Union Formation underlies the surface and was never mantled by Pleistocene ice. They are uncommon in the areas covered by glacial drift. Most of the areas of extensive soil sliding are in the unglaciated area south of the Little Missouri River in southern McKenzie County and to the south, and south of the Knife River to the southeast. The counties mainly affected are Golden Valley, Billings, Stark, Slope, Hettinger, Bowman, Adams, and the western parts of Morton and Grant. Soil slide scars are common on the upland along U.S. Highway 85 southward from the Little Missouri River and along Interstate Highway 94 west of exit 25, 6 or 7 miles west of New Salem. They are especially abundant south of the Heart River in Stark County (fig. 19), and are common on some lesser slopes near Chalky Buttes (fig. 20) and HT (Black) Butte in Slope County. Soil slides also have affected many slopes, some quite steep, in the badlands area of the Little Missouri River valley in Theodore Roosevelt National Memorial Park, South Unit, and south of Medora.

Soil slides in southwestern North Dakota take place locally on slopes that may be as gentle as 5 degrees, but most commonly occur on somewhat steeper slopes. Slopes of more than
10-15 degrees in the nonglaciated areas are especially susceptible to soil slides.

Till of the extensive cover of ground moraine in the glaciated areas appears to be generally unaffected by soil slides. This likely is because the deposits are to young to have a well-developed soil profile with an appreciable $\mathrm{B}$ horizon.

Although soil slides affect only the surficial materials to rather shallow depths, they constitute a widespread form of ground instability that can cause tremendous losses if it is not recognized and anticipated in planning and design stages.

\section{SUBSIDENCE}

Subsidence is the gradual downward sinking or settling of a part of the Earth's surface with little or no horizontal motion (definition of subsidence modified from American Geological Institute, 1972). Subsidence can be caused naturally by solution of soluble rocks and creation of a subsurface void into which the overlying beds can sink. Withdrawal of fluids from porous beds can cause compaction and subsidence. Removal of ore or coal from underground mines creates space into which overlying beds may subside if the lithostatic 


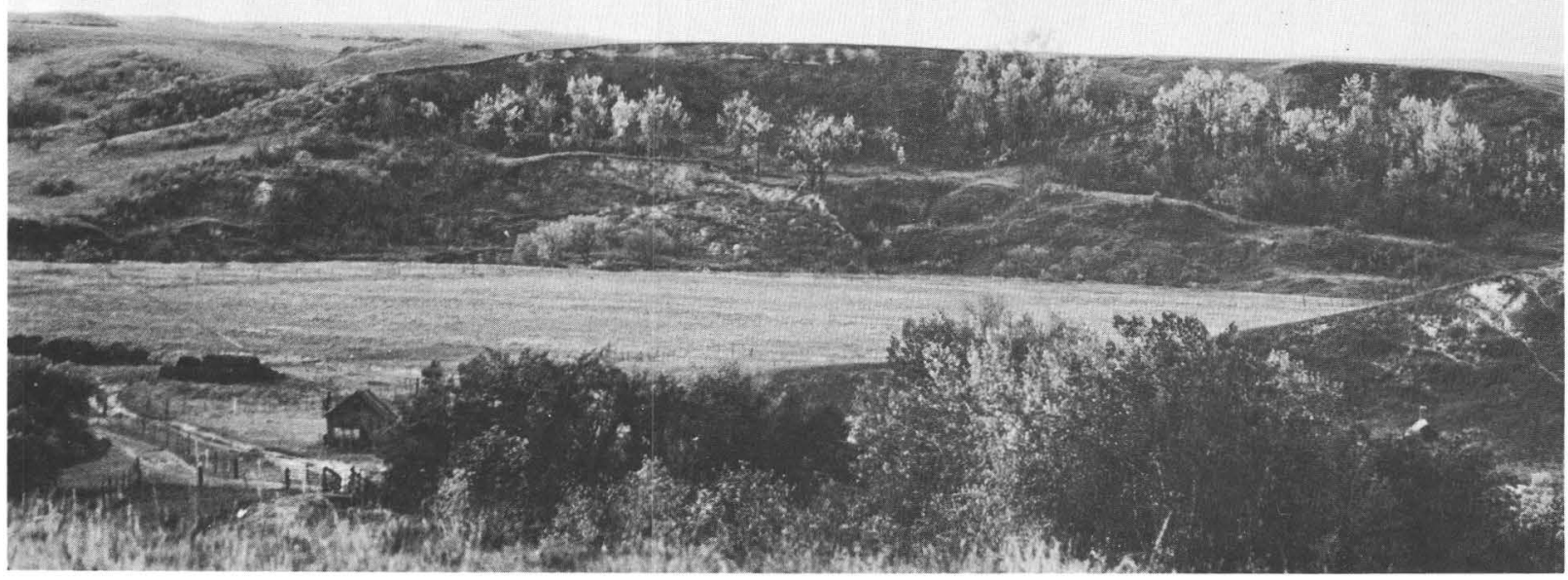

Figure 16.--Landslide along the south wall of the Heart River valley south of Taylor, North Dakota.

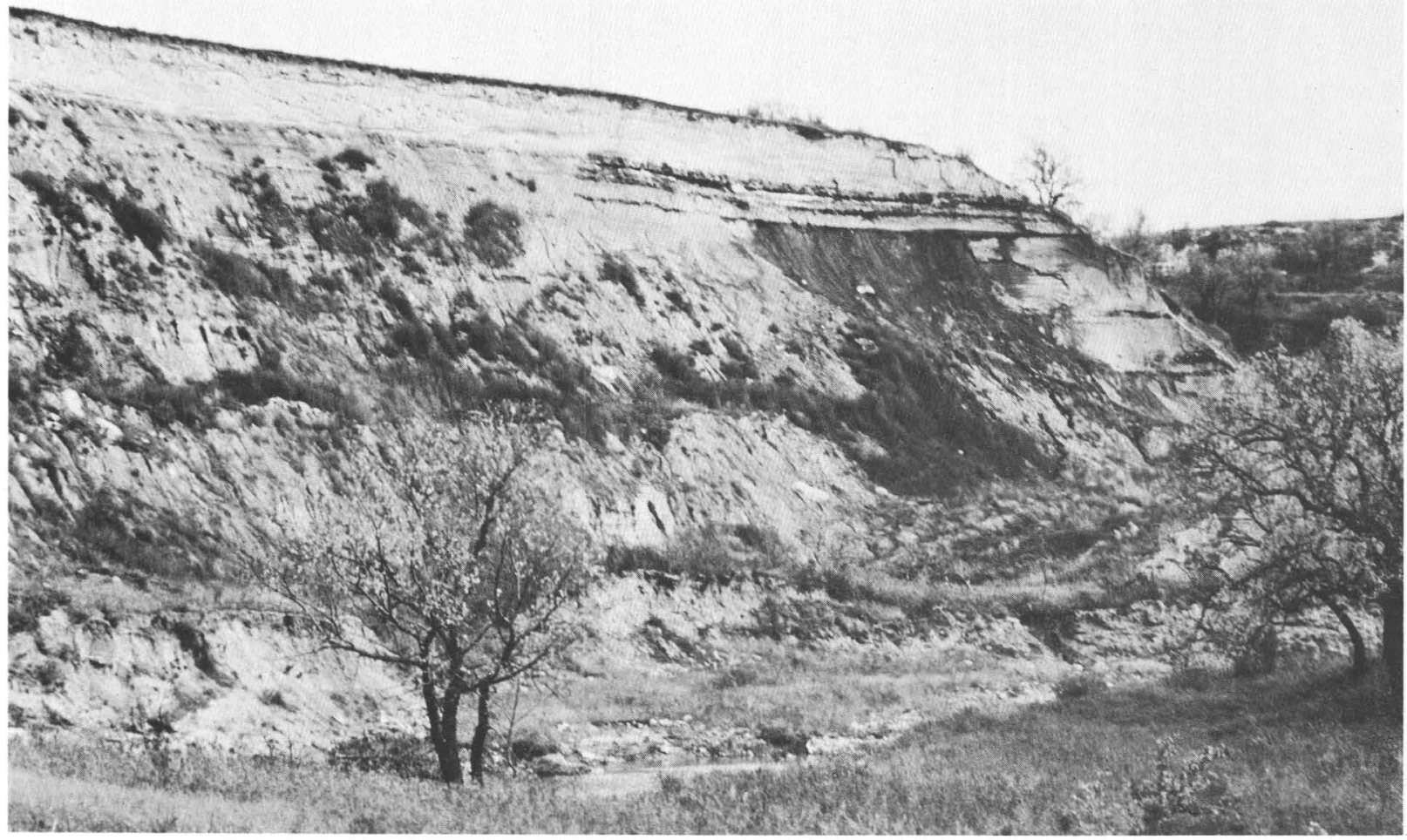

Figure 17.--Sentinel Butte Member of the Fort Union Formation exposed in cutbank on north side of Heart River valley south of Taylor, North Dakota. Bluff 24-30 m (80-100 ft) high. Note thin lignite seams that probably contribute to wetting of the siltstones and claystones of the Sentinel Butte Member and facilitate landsliding. 


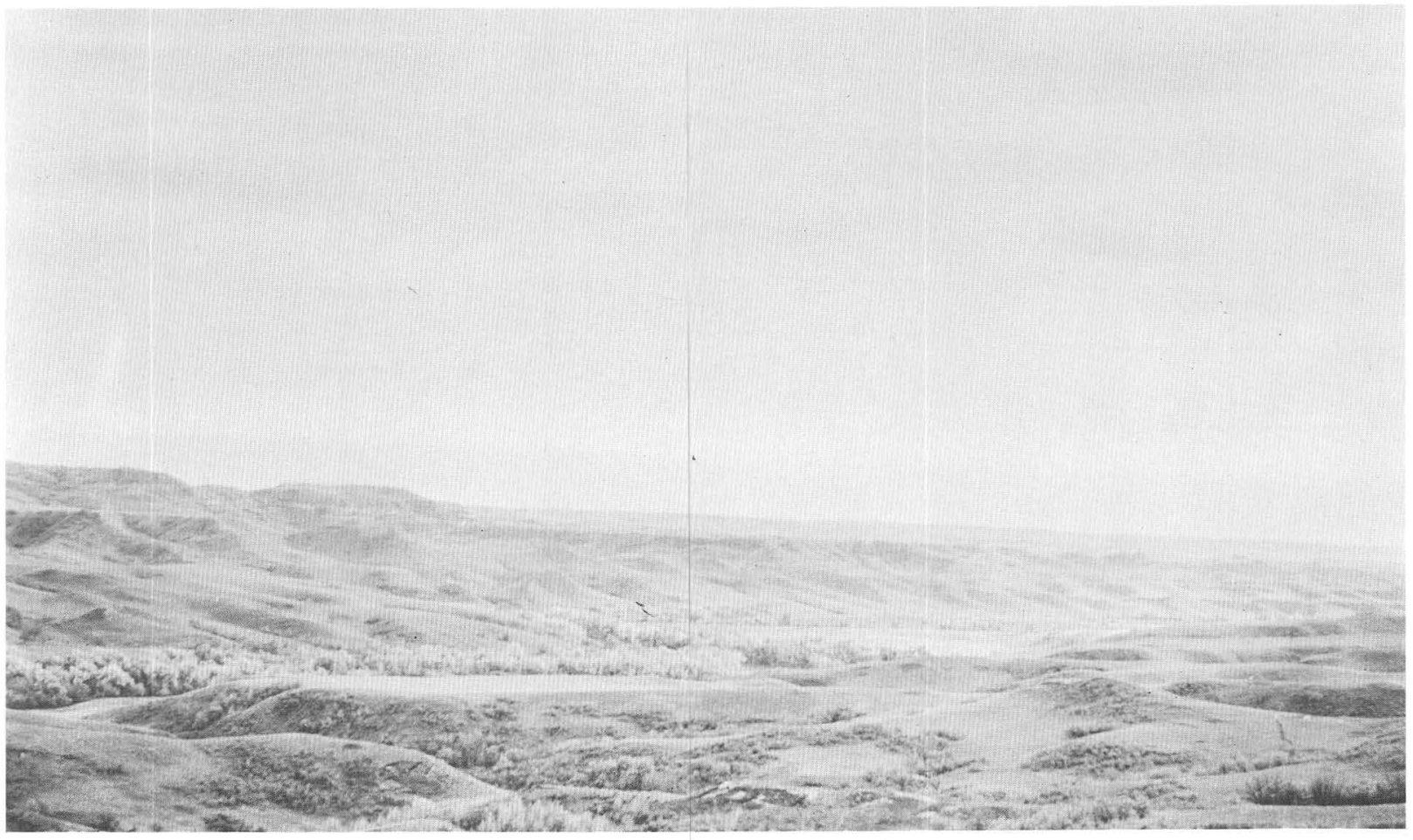

Figure 18.--Landslides along east side of Heart River valley east of Almont, North Dakota. Entire valley wall is landslide complex.

load exceeds the shear strength of the rocks. Similarly, the burning of coal beds, which can occur naturally because of ignition on the outcrop by spontaneous combustion or lightning, creates a space or a void into which overlying beds may subside.

Subsidence has occurred at several places in western North Dakota, both above old underground mines and above naturally burned-out coal beds.

\section{SUBSIDENCE OVER MINED-OUT AREAS}

Subsidence over old mine workings has taken place at several localities in western North Dakota. Some of these subsidence areas are of spectacular proportions, with subsidence pits outlining the underground rooms over tens of acres. Those at Beulah (fig. 21), Haynes (fig. 22), Wilton, Belfield, and Lehigh are especially impressive. Smaller areas of subsidence are located east of Belfield, at Scranton, and west and north of Bowman.

Underground mining of lignite began early in North Dakota. Coal was mined near Minot in the 1880's (Andrews, 1939). The earliest year for which lignite production was reported in North Dakota was 1884, when 31,752 metric tons (35,000 English tons) was produced

(Brandt, 1953, p. 57). Most early-day mining was underground, and in 1927, 146 underground mines produced 831,621 metric tons $(916,690$
English tons) while 81 strip mines produced 555,627 metric tons (612,464 English tons) (Brandt, 1953, p. 58). Underground mining in North Dakota, then, was the predominant method of lignite mining through the early part of this century, but by 1958 only one underground mine remained in operation (Landis, 1973, p. 45). Many localities in the state have old underground workings beneath the surface, but subsidence has not taken place above all of them.

Marked subsidence has taken place above large underground mines that were operating at the turn of the century at Lehigh (about $8 \mathrm{~km}$, or about $5 \mathrm{mi}$ east of Dickinson) and Wilton (east of the Missouri River north of Bismark) (Babcock, 1901; Wilder, 1902). The underground mining at Beulah and Haynes began later. The Washburn mine at Wilton, the largest mine operated in the state in 1902 (Wilder, 1902, p. 60), was an underground operation with an access shaft to a coal seam $18 \mathrm{~m}$ (60 ft) below the surface. The coal seam ranged from 2.4 to $4 \mathrm{~m}$ ( 8 to $13 \mathrm{ft}$ ) in thickness, and was worked by the double entry and room and pillar system, the rooms being about $5.2 \mathrm{~m}$ (17 ft) wide

(Wilder, 1902, p. 61). The coal seam in a strip mine currently operating near the subsidence area near Haynes, in southern Adams County, is only about 4.6 or $6 \mathrm{~m}$ ( 15 or $20 \mathrm{ft}$ ) below ground level, and the underground operation probably 


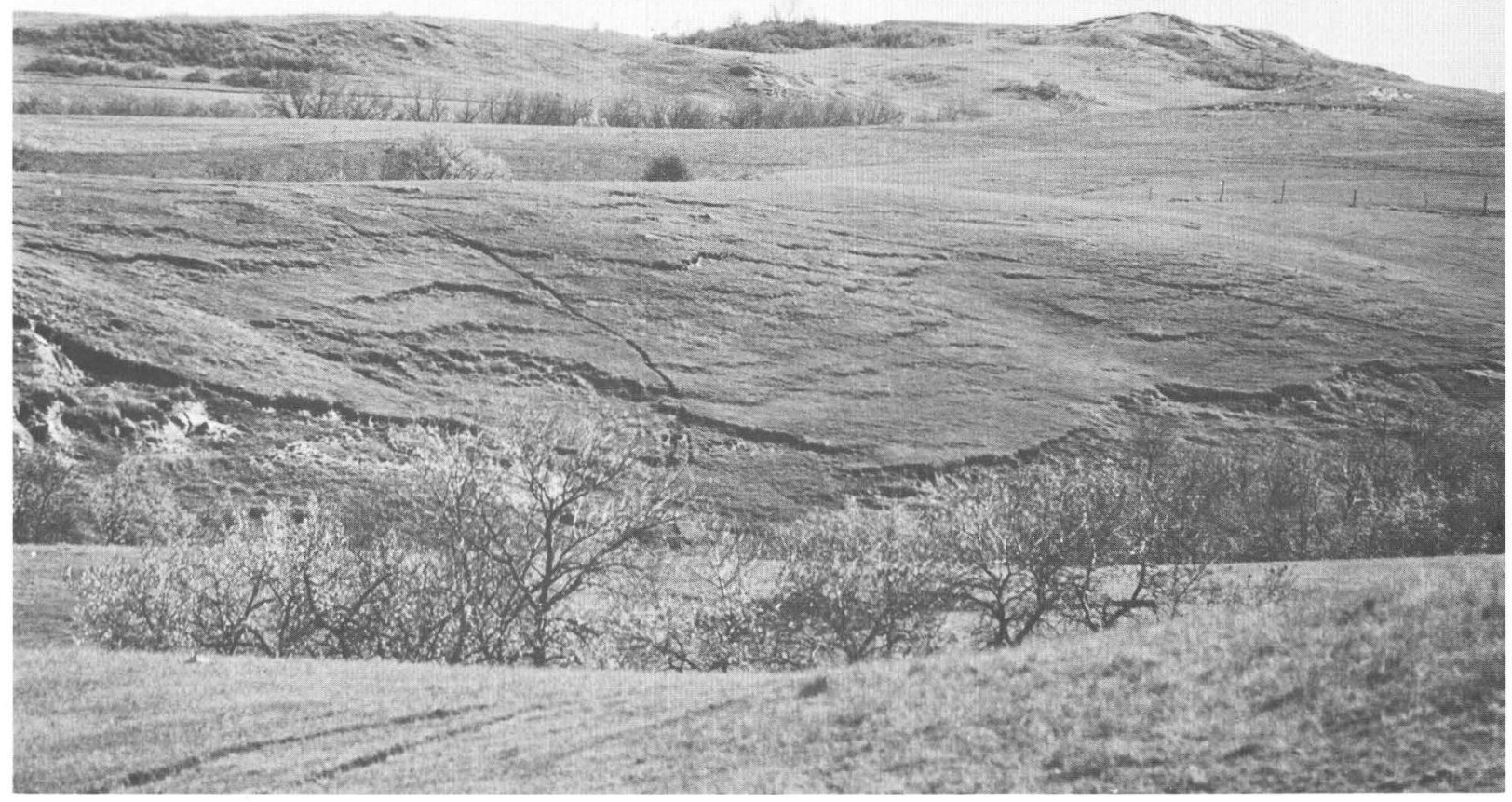

Figure 19.--Soil slide scars on west-facing slope, 3 miles south of the Heart River south of Taylor, North Dakota. Scars are apparent on both near and distant slopes.

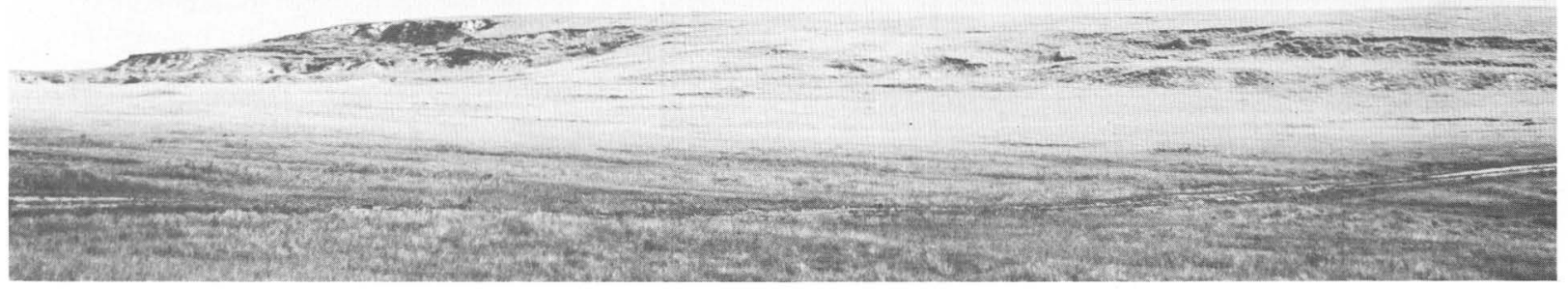

Figure 20.--Soil slide scars on the north end of Chalky Buttes, east of U.S. Highway 85 north of Bowman, North Dakota. 


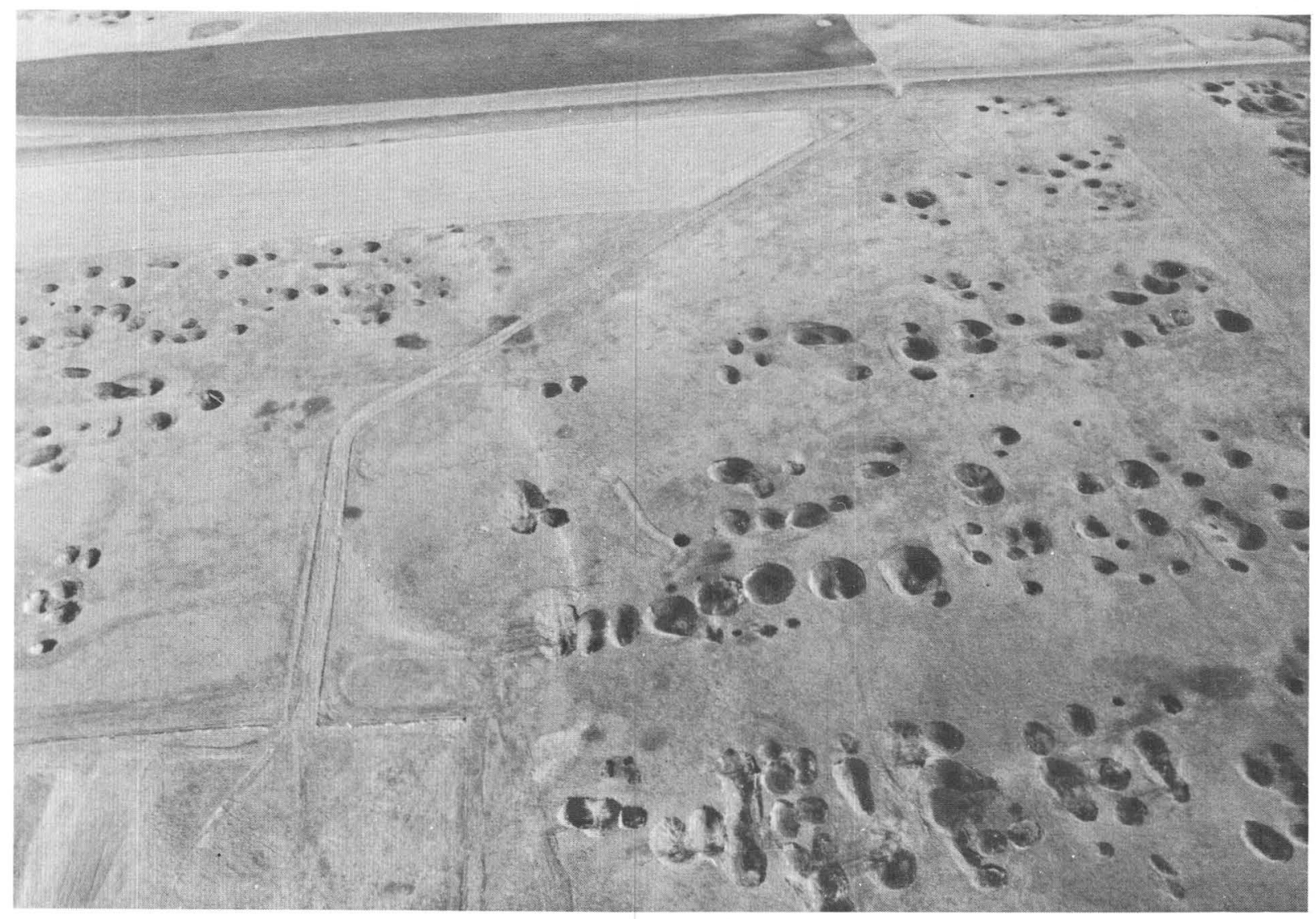

Figure 21.--Subsidence pits over old underground coal-mine workings near Beulah, North Dakota. Photograph by Richard C. Dunrud.

had about $30 \mathrm{~m}$ (100 ft) or less of overburden over most of its extent (fig. 23).

Many large underground mines were in operation along the Des Lacs and Souris Rivers around the turn of the century, but they had much more overburden over the mined coal beds: 61-67 m (200-220 ft) at the North Dakota Lignite and Brick Company mine in sec. 10, T. 155 N., R. 83 W. (Wilder, 1902, p. 115) and more than $91.5 \mathrm{~m}$ (300 ft) in the New Era Mine in sec. 15, T. 155 N., R. 84 W., near Minot (Wilder, 1902, p. 164). Subsidence pits have not formed where the overburden was thick.

From these data, it is apparent that subsidence has taken place over old underground mines where the thickness of the overburden was $30 \mathrm{~m}(100 \mathrm{ft})$ or less, but that subsidence has not taken place where the overburden was $61 \mathrm{~m}$ (200 ft) or more in thickness.

\section{SUBSIDENCE OVER NATURALLY BURNED-OUT COAL SEAMS}

Widespread fused and oxidized layers of rock called clinker or scoria, that were reddened and hardened by heat from burning coal beds, indicate that lignite coal beds have ignited and burned at many places throughout the centuries. When a thick coal bed burns, it is almost completely consumed, and only a little ash and a lot of space is left where formerly there was a coal bed. The overlying rock layers commonly collapse to fill the space formerly occupied by the coal. Surface expression of this collapse is subsidence. Such subsidence has happened many times in the past, and is still happening today.

Subsidence over a currently burning coal bed is spectacularly illustrated near the Little Missouri River at Burning Coal Vein Park in Custer National Forest, northwest of Amidon (fig. 24). There the U.S. Forest Service has established a park and picnic ground, and an exhibit at a special observation area provides the public with an explanation of the ground failure caused by the burning of the subsurface coal bed (fig. 25). The fire has been burning in the Burning Coal Vein since before man came to the area, and has caused subsidence and rupturing of surface beds over many acres of land. 


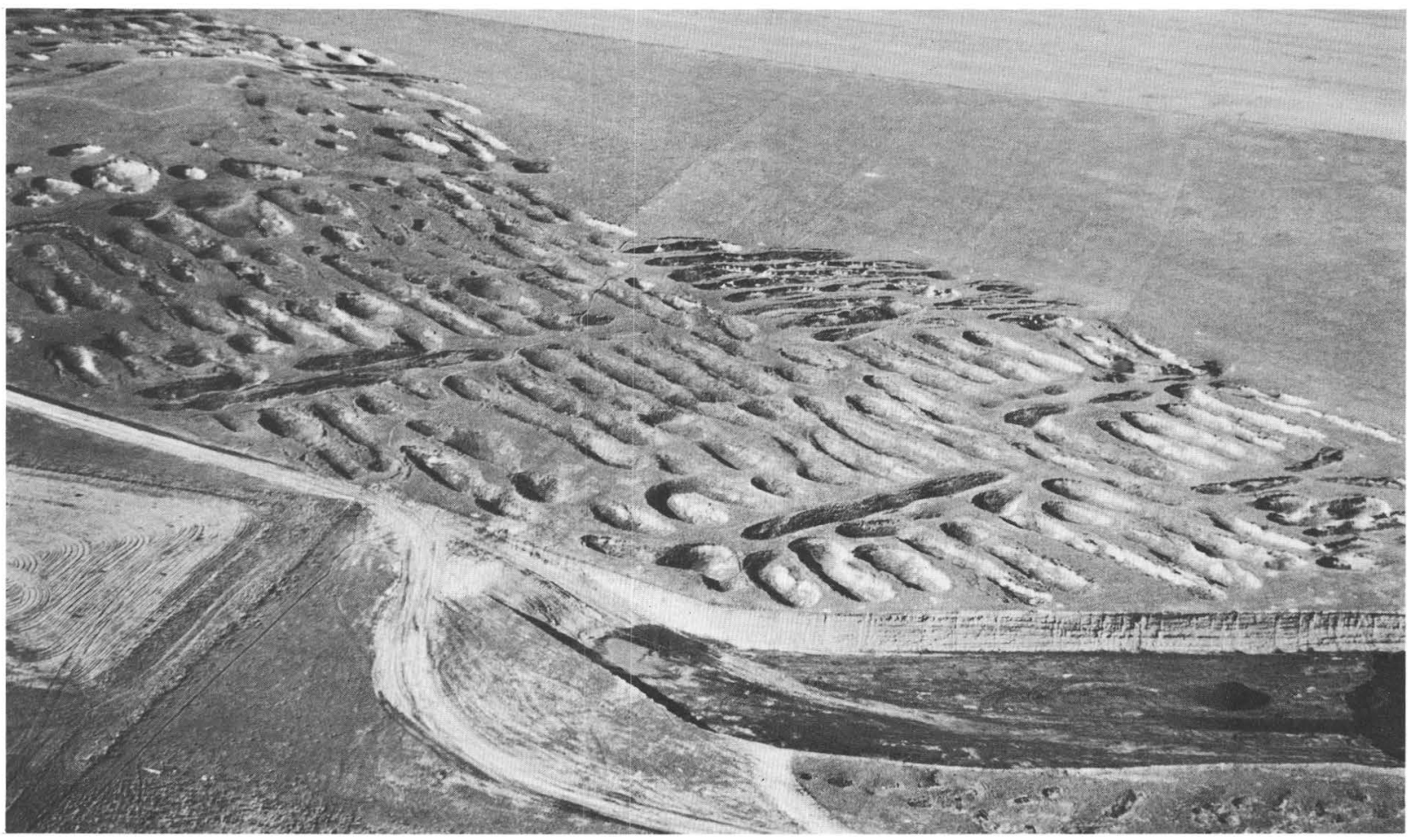

Figure 22.--Aerial view northwest across subsidence pits over old underground coal mine workings east of State Highway 8 north of Haynes, North Dakota. Strip mine operation of Arrowhead Coal Company in foreground.

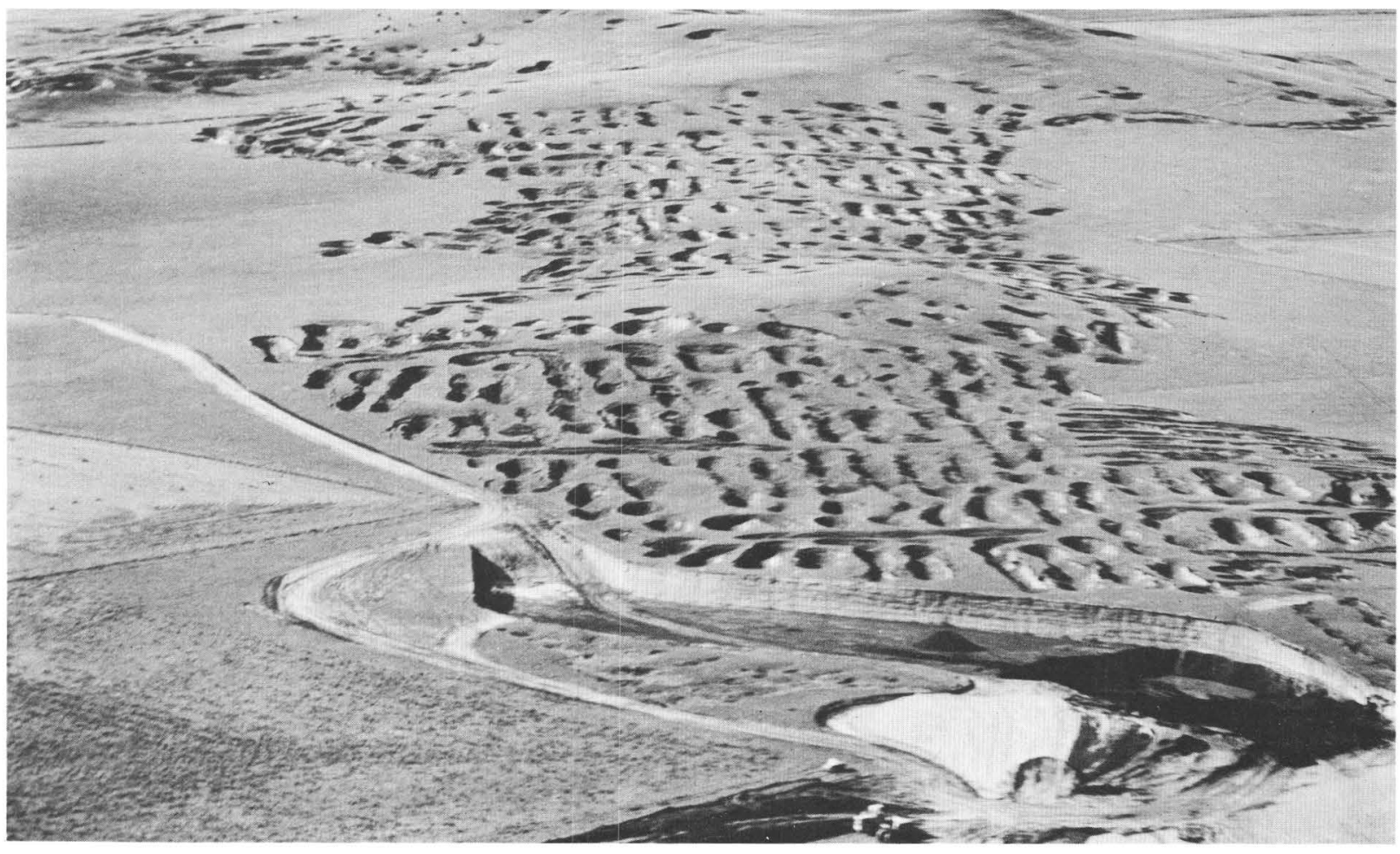

Figure 23.--Aerial view looking northwest across subsidence pits and strip mine of Arrowhead Coal Company north of Haynes, North Dakota. High wall in strip mine above coal bed only 4.6-6 m (15-20 ft) high. Note equipment for scale. 


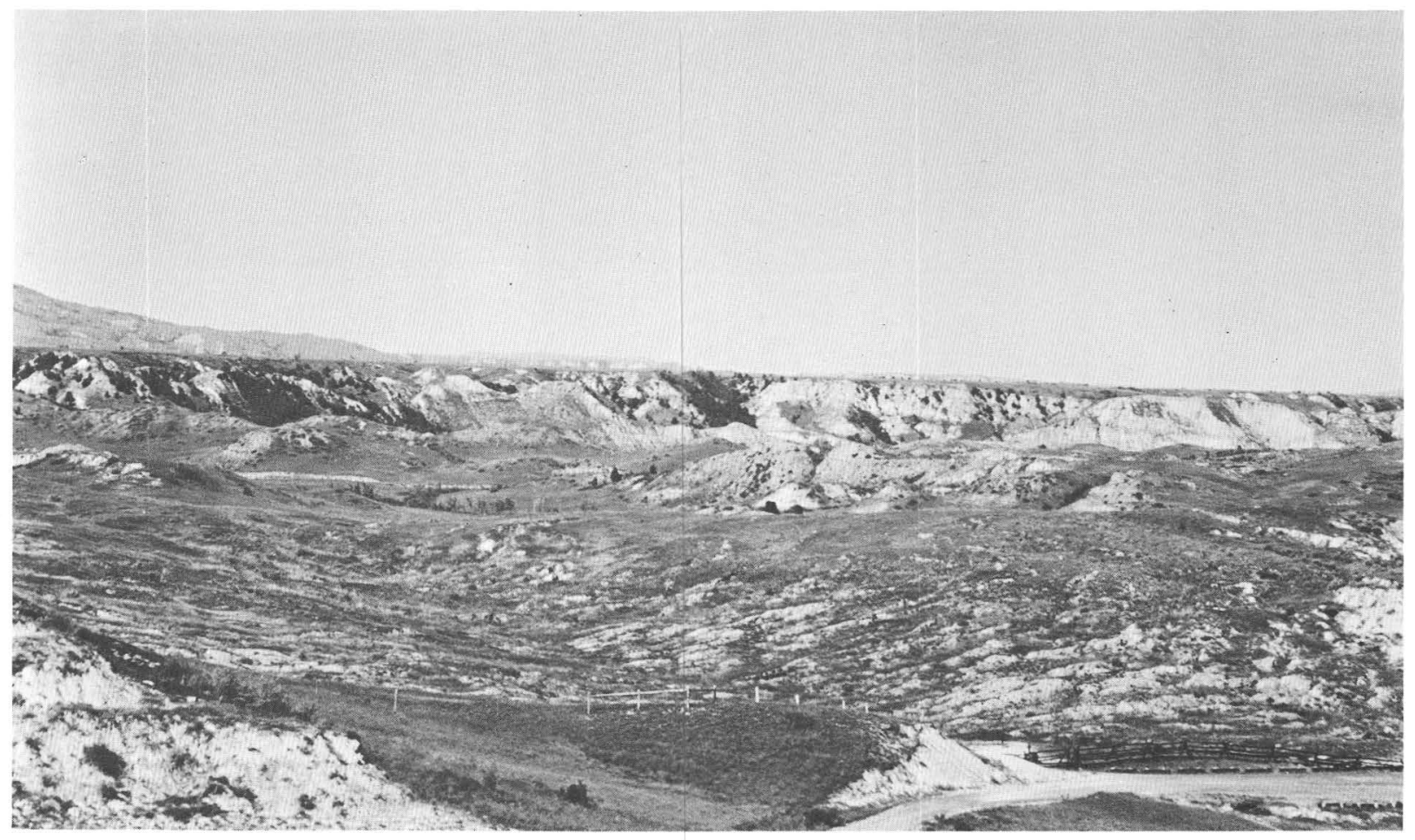

Figure 24.--View west to Burning Coal Vein subsidence area, Custer National Forest, northwest of Amidon, North Dakota. Forest Service observation area beyond curve in lower right.

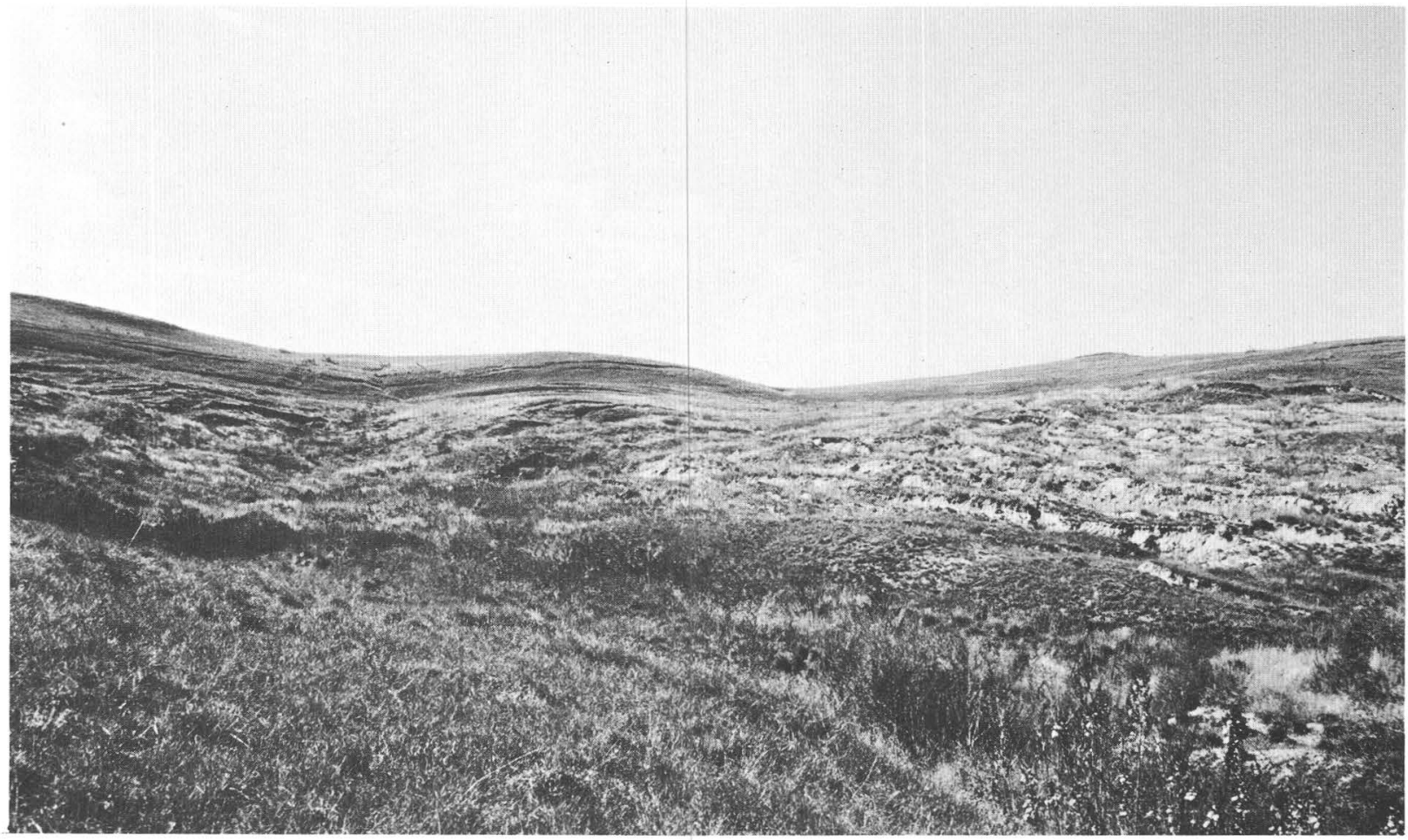

Figure 25.--Subsidence above burning underground lignite bed, Burning Coal Vein Park, Custer National Forest, northwest of Amidon, North Dakota. 


\section{SUMMARY}

Large slump-earthflow type landslides in western North Dakota occur mainly on the steep slopes of the high buttes (in southwestern North Dakota) and along parts of the entrenched valleys of the Des Lacs, Missouri, Little Missouri, and Heart Rivers. Because they are localized on steep slopes and in entrenched valleys, the landslides are not likely to be a major hazard to energy development. However, the possibility of reactivating an old, stabilized landslide mass by loading its head, excavating at its toe, or introducing water into the main mass of slide material, should be recognized when highway, railroad, or viaduct construction requires crossing an old, recognized slide area.

Soil slides, though affecting only the upper part of the soil profile, constitute a greater potential hazard to energy development sites than the more impressive large landslides. Much of the unglaciated area south of the Little Missouri River in western North Dakota is highly susceptible to soil sliding, especially if much water is introduced, either artificially or by heavy precipitation. When colluvium and weathered Fort Union Formation become wet, even on gentle slopes, soil slides can occur, and this tendency for ground failure should be given careful consideration whenever any type of construction is to be undertaken in this region.

Most large-scale underground coal-mining operations in western North Dakota ended more than 40 years ago and much subsidence has taken place over the old underground mines. The underground mines along the Des Lacs and Souris valleys northwest of Minot were abandoned even earlier, but the surface above them has not subsided in 60 or 70 years. The greatest potential for damage in western North Dakota as a result of unstable ground conditions is, then, the potential for soil sliding as a result of saturation of colluvium and weathered Fort Union Formation on slopes exceeding $5^{\circ}$ in the unglaciated areas south of the Little Missouri River. Care should also be taken, however, to ensure that old recognized landslides of the slump-earthflow type are not reactivated.

\section{REFERENCES CITED}

American Geological Institute, 1972, Glossary of geology, Gary, Margaret, McAfee, Rotert, $\mathrm{Jr}$. , and Wolf, C. L., eds., 805 p. and 52 p. bibliography.

Andrews, D. A., 1939, Geology and coal resources of the Minot region, North Dakota: U.S. Geological Survey Bulletin 906-B, p. 43-84.

Babcock, E. J., 1901, First Biennial Report: North Dakota Geological Survey, 103 p.

Brandt, R. A., 1953, Lignite resources of North Dakota: U.S. Geological Survey Circular 226, 78 p.

Landis, E. R., 1973, Coal, in Mineral and water resources of North Dakota, Report for the Committee on Interior and Insular Affairs: United States Senate, Part I, p. 45-52.

Lemke, R. W., and Kaye, C. A., 1953, Geology of the Bowbells quadrangle, North Dakota: U.S. Geological Survey Geologic Quadrangle Map GQ-26, scale $1: 62,500$.

Wilder, F. A., 1902, Second Biennial Report: North Dakota Geological Survey, 262 p. 
